\title{
New and Poorly Known Species of Peniagone (Holothuroidea, Elpidiidae) from the Northwest Pacific Ocean with Discussion on Phylogeny of the Genus
}

\author{
Antonina Kremenetskaia ${ }^{1}\left(\mathbb{D}\right.$, Andrey Gebruk ${ }^{1} \mathbb{D}$, Claudia H. S. Alt ${ }^{2}$ and Nataliya Budaeva ${ }^{1,3, *}$ \\ 1 Shirshov Institute of Oceanology, Russian Academy of Sciences, 117218 Moscow, Russia; \\ antonina@ocean.ru (A.K.); agebruk@gmail.com (A.G.) \\ 2 City of Bristol College, Bristol BS1 5UA, UK; delphi11@googlemail.com \\ 3 Department of Natural History, University Museum of Bergen, University of Bergen, 5020 Bergen, Norway \\ * Correspondence: Nataliya.Budaeva@uib.no
}

Citation: Kremenetskaia, A.; Gebruk, A.; Alt, C.H.S.; Budaeva, N. New and Poorly Known Species of Peniagone (Holothuroidea, Elpidiidae) from the Northwest Pacific Ocean with Discussion on Phylogeny of the Genus. Diversity 2021, 13, 541. https://doi.org/10.3390/d13110541

Academic Editor: Michael Wink

Received: 27 September 2021

Accepted: 22 October 2021

Published: 28 October 2021

Publisher's Note: MDPI stays neutral with regard to jurisdictional claims in published maps and institutional affiliations.

Copyright: (c) 2021 by the authors. Licensee MDPI, Basel, Switzerland. This article is an open access article distributed under the terms and conditions of the Creative Commons Attribution (CC BY) license (https:// creativecommons.org/licenses/by/ $4.0 /)$.

\begin{abstract}
The northwest Pacific fauna of Peniagone includes at least seven species. In the present study we considered the following six species: Peniagone dubia and P. mus are re-described, P. minuta and $P$. saveljevae are described as new to science, additional information is provided on $P$. vitrea and $P$. cf. purpurea. Peniagone japonica was not included in the analysis. A potentially new species Peniagone sp. "miniatura" was distinguished based on morphological and molecular data but not formally described due to insufficient material. In the northwest Pacific, the species of Peniagone are distributed from 2400 to $8200 \mathrm{~m}$. The bathymetric range of most of the species is narrow except for $P$. mus being also one of the deepest representatives of the genus. Only one species, $P$. vitrea, is known outside the northwest Pacific region. Partial sequences of COI and 16S rDNA were obtained for provisionally ten species of the genus (four of them from the northwest Pacific) and two other species of Elpidiidae which were used as an outgroup in phylogenetic analyses. The phylogenetic analyses results suggest that the northwest Pacific species of Peniagone are not closely related.
\end{abstract}

Keywords: Echinodermata; Elasipodida; deep-sea holothurians; taxonomy; abyssal and hadal fauna

\section{Introduction}

The genus Peniagone is the most species rich in the family Elpidiidae including 33 valid species according to WoRMS [1]. The genus commonly occurs in all oceans except for the Arctic, with the highest species diversity in the Antarctic and the Pacific Ocean [2]. The vertical distribution of Peniagone ranges from 220 to $8660 \mathrm{~m}$, with most records at the lower bathyal and abyssal depths. The genus is characterized by a high diversity of morphological features such as form and size of its velum, the position and size of its tube feet and the configuration of the tentacle crown. These features are of particular interest for questions on colonization and adaptation to the deep-sea environments since in Peniagone species they are related to the swimming mode and/or adaptations to balancing of the body on substrate, in the presence of the near-bottom currents [3].

The deep-sea northwest Pacific echinoderm fauna is one of the most species rich [4]. Data on the northwest Pacific deep-sea holothurians began accumulating since the HMS Challenger, USFS Albatross and the local Japanese cruises, from 1875 to the early 20th century [5-7]. The Zoological Institute in Leningrad (now St. Petersburg, Russia) has conducted numerous cruises to the Bering Sea and to the Sea of Okhotsk, which resulted in a series of papers on the echinoderm taxonomy [8-12]. Since 1949, the northwest Pacific has been explored by the Soviet RV Vityaz expeditions which collected extensive material from the Kuril-Kamchatka, Aleutian, Japan and Izu-Bonine trenches and adjacent abyssal and bathyal areas. Based on these materials, several studies were published on Myriotrochidae [13,14], Elpidia [15], Kolga [16] and Psychropotes [17]. Despite relatively 
extensive historical explorations in the region, the recent deep-sea cruises KuramBio [18], SokhoBio [19] and KuramBio II [20] collected many species and even genera new to science $[17,21]$, most of them remaining undescribed.

So far, the northwest Pacific fauna of Peniagone was not sufficiently explored. Among six species reported for the area, $P$. dubia (Djakonov et Saveljeva), P. japonica Ohshima and P. mus Djakonov are known only from the original descriptions, all of them lacking information on the morphological characters presently used for species delimitation. Another species common to the area identified as Peniagone cf. incerta (Théel) in Mironov et al. [4] requires further investigation due to identification uncertainty. Two more species, P. purpurea Théel and P. gracilis (Ludwig), reported by Gebruk [22] are also in need of re-examination since some of their morphological features differ from those in the original descriptions. In the present study, we examine materials collected in recent expeditions to the northwest Pacific and re-examine some of earlier RV Vityaz collections from this area. In particular, we re-describe two poorly known species, Peniagone dubia and P. mus, describe two species new to science, $P$. minuta and $P$. saveljevae and provide additional information on P. vitrea Théel and P. cf. purpurea. (Figures 1-8). Molecular data were obtained for P. mus, $P$. saveljevae and P. cf. purpurea and used for phylogenetic analysis (Figures 9 and 10).

\section{Materials and Methods}

Specimens were collected during three German-Russian cruises: KuramBio (2012), SokhoBio (2015) and KuramBio II (2016). Additionally, the specimens obtained during the following cruises of the RV Vityaz were re-examined: 8 (1951), 19 (1954), 22 (1955), 29 (1958), 39 (1966), 43 (1968), 45 (1969), 52 (1972) and 57 (1975). All specimens were collected using benthic trawls and mainly preserved in ethanol. Records of species with locality and sampling data are published through GBIF [23].

Specimens were identified based on standard characters used for elpidiid holothurians [24]. Features of external morphology were examined using a stereomicroscope; slide preparations of calcareous epidermal elements (ossicles) of dorsal and ventral sides were examined using a compound microscope Olympus BX43.

Abbreviations used for specimen repositories: IORAS, P.P. Shirshov Institute of Oceanology, Moscow, Russia; MIMB, Museum of the A.V. Zhirmunsky National Scientific Center of Marine Biology, Vladivostok, Russia; NHM, Natural History Museum, London, UK; NMNH, National Museum of Natural History, Washington, USA; NOCS, National Oceanography Centre, Southampton, UK; SGN, Senckenberg Research Institute and Natural History Museum, Frankfurt, Germany; ZIN, Zoological Institute, St. Petersburg, Russia; ZMBN, University Museum of Bergen, University of Bergen, Norway. Specimens from SokhoBio, KuramBio and KuramBio II cruises currently stored in IORAS will be later deposited at MIMB (SokhoBio and KuramBio) and SGN (KuramBio II).

Samples for molecular analyses were taken during the KuramBio, SokhoBio and KuramBio II cruises. Other sequences were obtained in GenBank and BOLD; GenBank Accession Numbers and BOLD Process ID are listed in Tables S1 and S2. Laboratory work was performed in the DNA Lab of the University of Bergen, Norway. Fragments of cytochrome c oxidase subunit I (COI) and 16S ribosomal RNA (16S) were amplified and sequenced using the universal and specific echinoderm primers (Table S1) [25-29]. Genomic DNA was extracted with QuickExtract ${ }^{\mathrm{TM}}$ DNA Extraction Solution using the following protocol: $100 \mu \mathrm{L}$ of QuickExtract solution was added to each sample air-dried from ethanol, incubated for $45 \mathrm{~min}$ at $65^{\circ} \mathrm{C}$, following $2 \mathrm{~min}$ at $98^{\circ} \mathrm{C}$. Amplification was performed with TaKaRa Ex Taq HS version kit (Takara BIO, Kusatsu, Japan) in a $25 \mu \mathrm{L}$ reaction consisted of $1 \mu \mathrm{L}$ of DNA extract, $17.35 \mu \mathrm{L}$ of purified water, $2.5 \mu \mathrm{L}$ of $10 \times$ Ex Taq buffer, $2 \mu \mathrm{L}$ of dNTP mixture, $1 \mu \mathrm{L}$ of each primer and $0.15 \mu \mathrm{L}$ of TaKaRa Ex Taq HS. $16 \mathrm{~S}$ fragment was amplified under the following conditions: $94^{\circ} \mathrm{C}$ for $5 \mathrm{~min} ; 35$ cycles of $94{ }^{\circ} \mathrm{C}$ for $0.5 \mathrm{~min}, 50^{\circ} \mathrm{C}$ for $1.5 \mathrm{~min}$ and $72{ }^{\circ} \mathrm{C}$ for $1 \mathrm{~min}$; followed by final extension at $72{ }^{\circ} \mathrm{C}$ for $10 \mathrm{~min}$. COI fragment was amplified using the following conditions: $94^{\circ} \mathrm{C}$ for $12 \mathrm{~min}$; 35 cycles of $94{ }^{\circ} \mathrm{C}$ for $35 \mathrm{~s}, 48{ }^{\circ} \mathrm{C}$ for $70 \mathrm{~s}$ and $72{ }^{\circ} \mathrm{C}$ for $55 \mathrm{~s}$; followed by final extension at 
$72{ }^{\circ} \mathrm{C}$ for $10 \mathrm{~min}$. The amplified products were purified and sequenced using the Sanger method by Macrogen Europe (Amsterdam, Netherlands).

Sequences of Peniagone azorica von Marenzeller, P. coccinea Rogacheva et Gebruk and P. islandica Deichmann were obtained by C.A. from specimens collected on the ECOMAR cruise in 2010 [30]. DNA was extracted using QIAGEN DNeasy extraction kit following the manufacturers protocol. The PCR mix contained $0.2 \mu \mathrm{M}$ of each forward and reverse primer (Table S1), $1 \times$ QIAGEN Multiplex PCR Master Mix and $1 \mu \mathrm{g}$ template DNA in a final $20 \mu \mathrm{L}$ reaction volume. The PCR amplification conditions were as follows: $94{ }^{\circ} \mathrm{C}$ for $15 \mathrm{~min}$, followed by 35 cycles at $94^{\circ} \mathrm{C}$ for $30 \mathrm{~s}, 50{ }^{\circ} \mathrm{C}$ (for $16 \mathrm{~S}$ ) and $48^{\circ} \mathrm{C}$ (for COI) for $90 \mathrm{~s}$, $72{ }^{\circ} \mathrm{C}$ for $60 \mathrm{~s}$, and a final extension at $60^{\circ} \mathrm{C}$ for $10 \mathrm{~min}$.

Sequences were manually edited and assembled in Geneious v.7 software and then aligned in MEGA 7 [31] using MUSCLE algorithm. PartitionFinder2 [32] was used for selecting best-fit partitioning schemes and models of nucleotide evolution. The most appropriate models were HKY for COI codon positions 1 and 2, and $\mathrm{K} 81$ for COI codon position 3, and GTR + G for 16S. In the analysis based on concatenated COI and 16S data, GTR + I + G was most appropriate for all partitions. Phylogenetic trees were generated using Bayesian inference in MrBayes v. 3.2 [33] for single genes and for concatenated COI and $16 \mathrm{~S}$ matrix. For each dataset, two independent analyses each of four chains were run for 10,000,000 generations. The trees were sampled every 100th generation and $25 \%$ trees discarded as burn-in. Sufficiency of run convergence was evaluated using Tracer v.1.7.1. Genetic distances were calculated in MEGA 7 using Between Group Mean Distance algorithm.

\section{Taxonomy}

Order Elasipodida Théel, 1882

Family Elpidiidae Théel, 1882

Genus Peniagone Théel, 1882

\subsection{Peniagone dubia (Djakonov et Saveljeva in Djakonov et al. 1958)}

Figure 1A,B and Figure 2A-I.

Elpidiogone dubia Djakonov et al., 1958: 361-363, Figures 2-4 [11].

Peniagone dubia-Hansen, 1975: 144-145 [24]; Gebruk, 1990 (in Russian): 102-103, Figure 40 [22]; Mironov et al. 2018: 354 [34].

Type material. Six syntypes, ZIN 15626-1, RV Toporok, St. 15, Kuril-Sakhalin expedition, 27.08.1948, $45.05^{\circ} \mathrm{N}, 146.21^{\circ} \mathrm{S}, 2850 \mathrm{~m}$, http://zin.ru/collections/Holothuroidea/ specimen.html?Catalog_UID $=1344281483110961$ (accessed on 13 May 2021)

Material examined. Syntype of Elpidiogone dubia ZIN 1/15626 (slide preparation of skin ossicles); RV Vityaz, St. 5637, 09.09.1966, $44^{\circ} 29^{\prime}$ N, $149^{\circ} 06^{\prime}$ E, 2685-3035 m, IORAS ECH01295 and ECH01118, numerous fragments; St. 6671, 23.06.1972, $40^{\circ} 12^{\prime} \mathrm{N}, 143^{\circ} 35^{\prime} \mathrm{E}$, 2400-2720 m, IORAS ECH01476, 2 specimens and fragments of 70+ specimens.

Diagnosis (amended). Body width about $\frac{1}{4}$ of body length. Two pairs of free minute papillae behind velum. Tube feet four pairs free in the middle part of body, beginning at the level of the last pair of minute dorsal papillae; five-six pairs fused forming posterior lobe. Dorsal ossicles with arms $0.05-0.1 \mathrm{~mm}$ in length, curved to almost flat; two apophyses $0.02-0.1 \mathrm{~mm}$ in length, shorter or of same length with arms. Ventral ossicles with elongated central stem, arms $0.0-0.012 \mathrm{~mm}$ in length; small apophyses four rarely 2-3.

Description of material. Two preserved complete specimens were $27 \mathrm{~mm}$ long $/ 6.5 \mathrm{~mm}$ wide and $29 \mathrm{~mm}$ long $/ 7.2 \mathrm{~mm}$ wide. Both specimens were in poor condition, however main external morphological features can be ascertained. Body elongated (Figure 1A,B). Dorsal velum composed of two pairs of papillae, first pair longer than second. Tentacles 10 . Two anteriormost pairs of tube feet located in the anterior half of the body. Four anterior pairs of tube feet free, bigger than other pairs. Posterior tube feet decreased in size towards posterior end and partly fused. Dorsal ossicles (Figure 2F-I) with arms curved to varying degree, may look down almost vertically; two apophyses shorter than arms or the same 
length with arms; arms $0.08-0.1 \mathrm{~mm}$ in length, apophyses $0.05-0.1 \mathrm{~mm}$ in length; smaller ossicles also present with arms about $0.05 \mathrm{~mm}$ and apophyses $0.02-0.03 \mathrm{~mm}$; apophyses and arms with small spines. Ventral ossicles with elongated central stem, arms $0.0-0.012 \mathrm{~mm}$ in length; small apophyses usually four (one on each arm), but 2-3 apophyses also present.
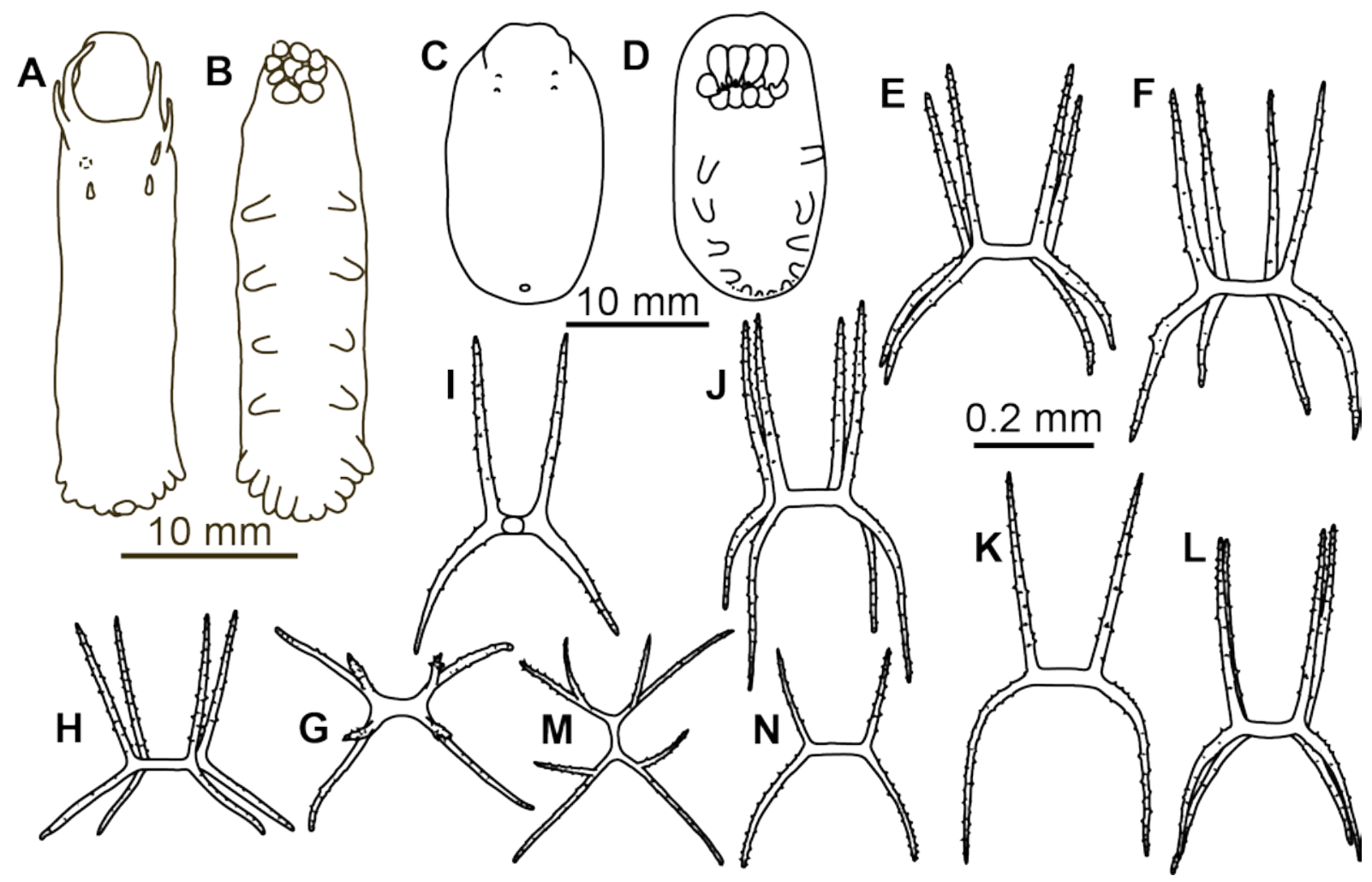

Figure 1. Peniagone dubia and P. minuta sp. nov. (A,B) P. dubia, dorsal and ventral view of specimen IORAS ECH01476; (C-L) P. minuta: (C,D) dorsal and ventral view of the holotype, dorsal (E-L) and ventral (M,N) ossicles, scale $0.2 \mathrm{~mm}$, a pair of arms and apophyses omitted on $(\mathbf{I}, \mathbf{K}, \mathbf{N})$.

Genetic data. No genetic data is available for this species.

Distribution. Type locality is in the southern part of the Sea of Okhotsk at depth $2850 \mathrm{~m}$. New records are in the northwest Pacific at depths 2400-3015 m (Figure 11).

Remarks. Description of the species was based on six poorly preserved specimens deposited at the Zoological Institute, St. Petersburg (Russia). In the original description, details of dorsal and ventral ossicles were missing. However, ossicles were found during re-examination of the original slides of the bodywall skin of the syntype ZIN 1/15626 (Figure 2A-E). Several ossicles were found with strongly curved arms that are characteristic of the dorsal skin in Peniagone (Figure 2A(left), B,D(right)). The species P. dubia is well distinguished by small dorsal ossicles with slender arms and only two apophyses. Among the species of Peniagone with ossicle arms $\sim 0.1 \mathrm{~mm}$ in length, including P. challengeri Théel, P. lugubris Théel, P. purpurea (Théel), P. intermedia Ludwig, P. papillata Hansen, P. vedeli Hansen, P. herouardi Gebruk, and P. dubia, only in the latter the dominant dorsal ossicles bear one pair of apophyses. The arrangement of tube feet with four anteriormost pairs free and other pairs fused forming the posterior lobe is the unique feature of external morphology differing P. dubia from the above listed species. 


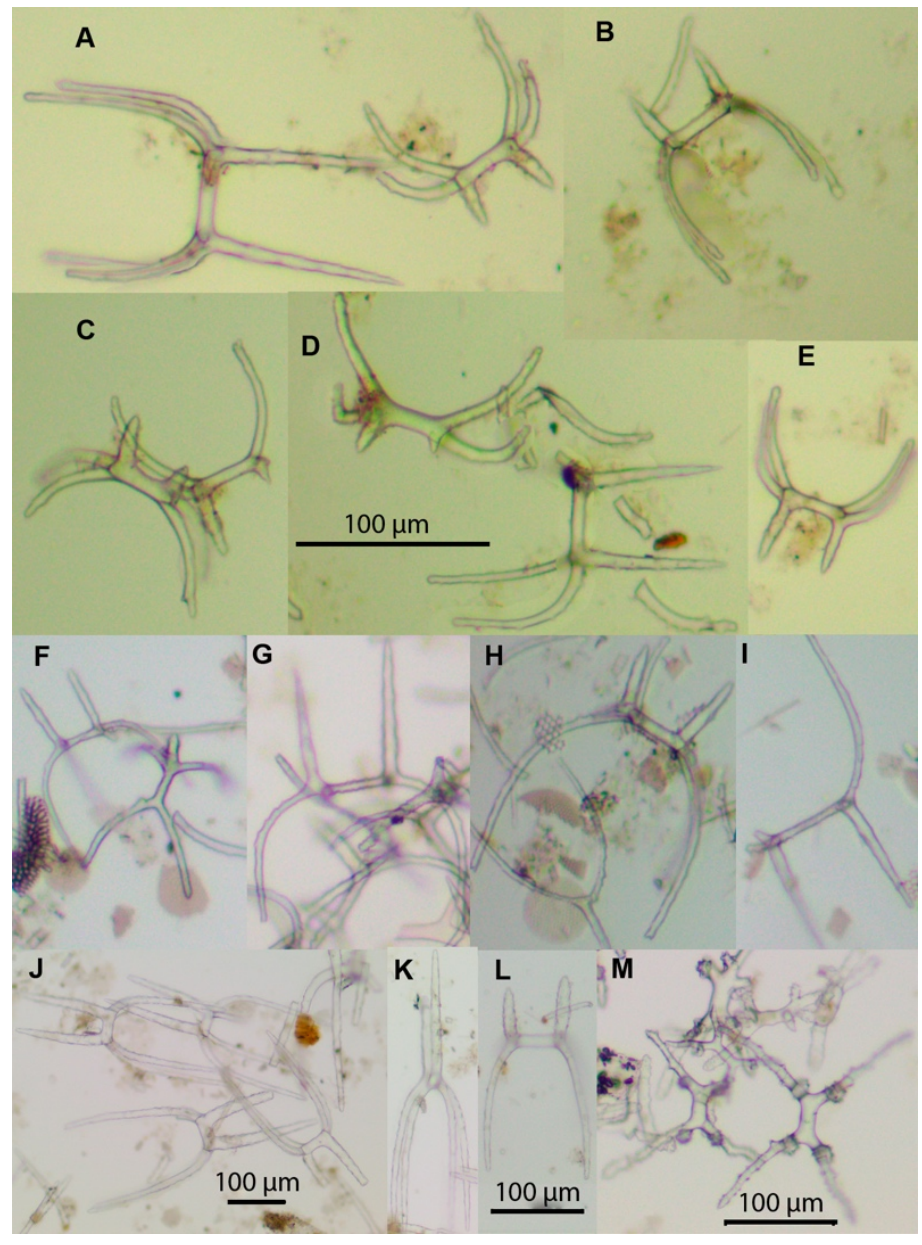

Figure 2. Ossicles of Peniagone dubia (A-I) and P. mus (J-M). (A-E) syntype of Elpidiogone dubia ZIN 1/15626, bodywall ossicles; (F-I) P. dubia, RV Vityaz, St. 5637, ECH01118, dorsal ossicles; (J-K,M) P. mus, R/V Sonne, St. 98, dorsal (J-K) and ventral (M) ossicles. (L) P. mus, R/V Vityaz, St. 956, dorsal ossicle.

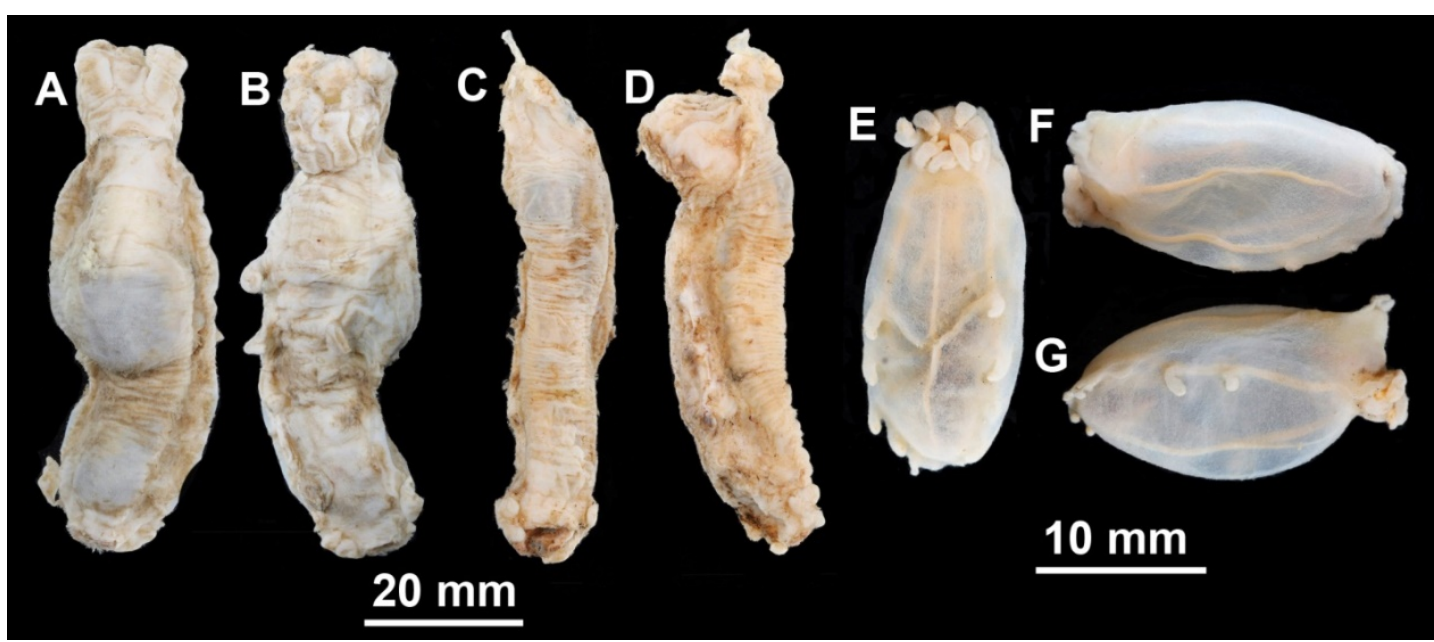

Figure 3. (A,B) Peniagone mus, IORAS ECH02148, dorsal and ventral view; (C,D) Peniagone saveljevae sp. nov., holotype, IORAS ECH02165, dorsal and lateral view; (E-G) Peniagone minuta sp. nov., paratype, IORAS ECH02170, ventral, dorsal and side view respectively. (A-D), scale $20 \mathrm{~mm}$; (E-G) scale $10 \mathrm{~mm}$. 

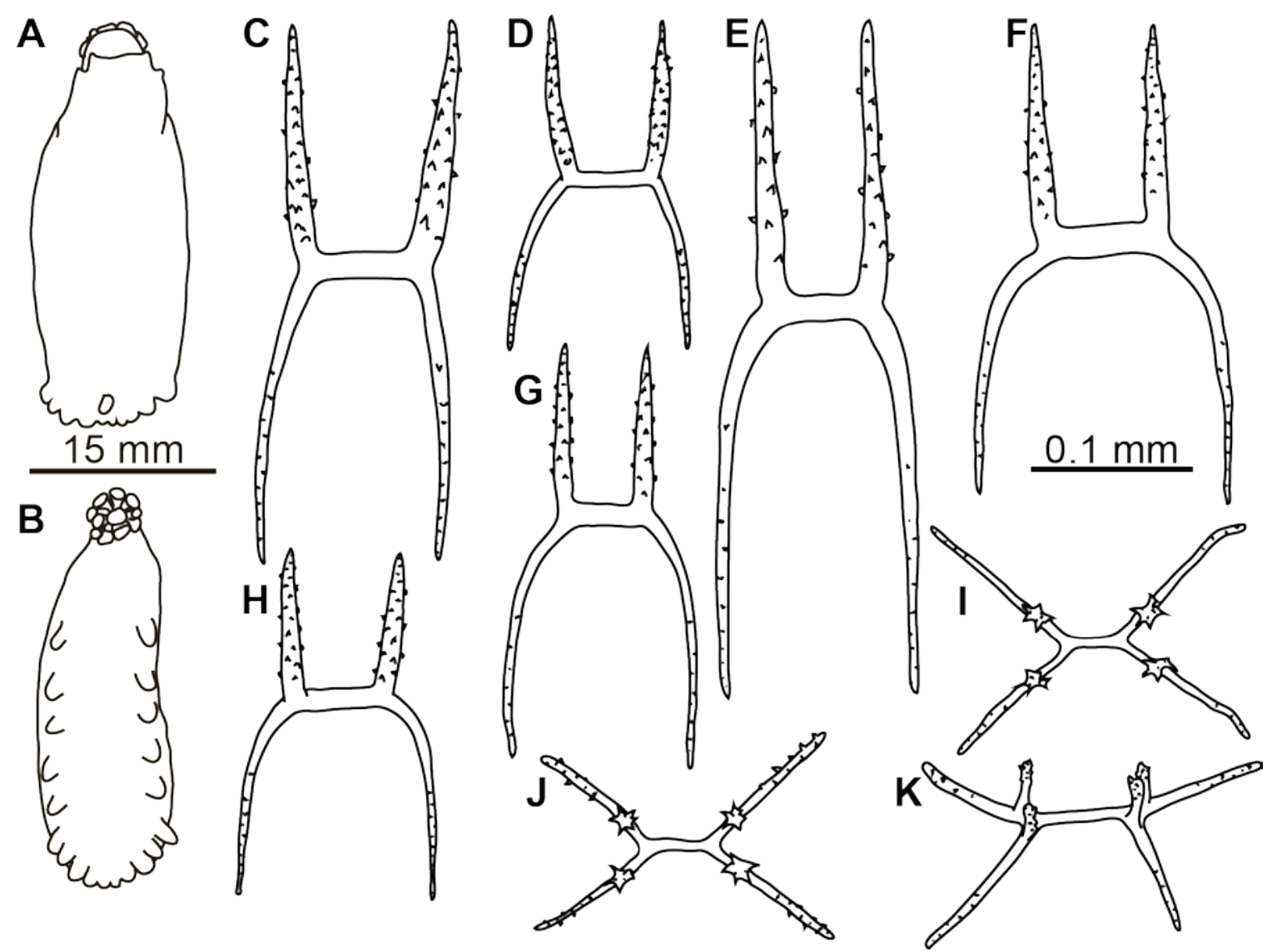

Figure 4. Peniagone mus. (A,B) RV Sonne, St. 03-10, dorsal and ventral view; (C-K) RV Sonne, St. 11-10, dorsal (C-H) and ventral (I-K) ossicles, scale $0.1 \mathrm{~mm}$, a pair of arms omitted in dorsal ossicles.

\subsection{Peniagone minuta Kremenetskaia et Gebruk sp. nov.}

Figure $1 \mathrm{C}-\mathrm{N}$ and Figure 3E-G.

Peniagone gracilis (Ludwig) -Gebruk, 1990 (in Russian): $96-97$ (partim.), Figure 36 (1-12) [22].

Holotype. Specimen $22 \mathrm{~mm}$ in length, IORAS ECH02166, RV Vityaz, St. 6085, 01.05.1969, Sigsbee Trawl, $50^{\circ} 48^{\prime} 6^{\prime \prime} \mathrm{N}, 173^{\circ} 29^{\prime} 0^{\prime \prime} \mathrm{W}, 6965-7000 \mathrm{~m}$.

Paratypes. 12 specimens, $14-21 \mathrm{~mm}$ in length, IORAS ECH02170, collected at same station as the holotype.

Additional material. RV Vityaz, St. 3491, 07.10.1955, Sigsbee Trawl, $30^{\circ} 34^{\prime} \mathrm{N}, 142^{\circ} 41.1^{\prime} \mathrm{E}$, 7305-7315 m, IORAS ECH01059, ECH01060, ECH01065, ECH01067, ECH01286, ECH01479, $\sim 50$ specimens; RV Vityaz, St. 6015, 25.04.1968, 26 ${ }^{\circ} 51^{\prime} \mathrm{N}, 165^{\circ} 32^{\prime} \mathrm{E}, 5850 \mathrm{~m}$, IORAS ECH01041, 2 specimens; St. 6085 (type locality), IORAS ECH01040, 84 specimens; St. 6144, 16.06.1969, Sigsbee Trawl, 51 ${ }^{\circ} 42^{\prime} 5^{\prime \prime}$ N, $168^{\circ} 5^{\prime} 0^{\prime \prime}$ W, 7200 m, IORAS ECH01052, 28 specimens; St. $6145,20.06 .1969$, Sigsbee Trawl, $51^{\circ} 1^{\prime} 19^{\prime \prime} \mathrm{N}, 174^{\circ} 35^{\prime} 5^{\prime \prime} \mathrm{E}, 7250 \mathrm{~m}$, IORAS ECH01114, 5 specimens; St. 7404, 09.05.1975, Sigsbee Trawl, 29 ${ }^{\circ} 14^{\prime}$ N, $142^{\circ} 30^{\prime}$ E, 6890-6770 m, IORAS ECH01050, 32 specimens; St. 7407, 11.05.1975, Galathea Trawl, $29^{\circ} 18^{\prime} \mathrm{N}, 143^{\circ} 15^{\prime} \mathrm{E}$, 6850-6740 m, IORAS ECH01054, 9 specimens.

Diagnosis. Body oval, convex, body length up to $35 \mathrm{~mm}$. Skin translucent, colorless, with dense ossicle layer. Tube feet 5-7 pairs, 3-4 anterior pairs bigger and 2-3 pairs smaller tube feet forming narrow posterior brim, anteriormost pair located at about a half of the body. Velum short, wide, two pairs of very small papillae behind velum. Dorsal ossicles with four spinous apophyses, apophyses slightly curved inside or straight, up to $0.35 \mathrm{~mm}$ long, from half to the same length as the arms; arms up to $0.4 \mathrm{~mm}$, spinous proximally, curved downwardly and inside. Ventral ossicles with four apophyses up to $0.2 \mathrm{~mm}$ in length, arms curved downwardly, up to $0.35 \mathrm{~mm}$. 
Description of material. Specimens from St. 6085 were in the exceptionally good condition (Figure $3 \mathrm{E}-\mathrm{G}$ ); other specimens in condition from poor to moderate. Body length from 11 to $24 \mathrm{~mm}$ (in type series) and up to $35 \mathrm{~mm}$ at other stations; body oval, convex on dorsum and sometime on ventrum (Figure 1C,D and Figure $3 E-G$ ). Ten tentacles; five anterior tentacles with a pair of long lobes on their aboral margin. Velum formed by two pairs of fully fused papillae, no free tips clearly visible in the preserved specimens. Dorsal papillae two pairs, very small, often lost. Tube feet located from about mid-body to the posterior end in most specimens although in some specimens anteriormost tube feet appeared in the anterior body half. Tube feet of four first pairs often the biggest in most of the specimens. Smaller posterior tube feet are often poorly visible, posterior brim narrow. Dorsal ossicles with arms mostly $\sim 0.2 \mathrm{~mm}$ long, occasionally up to $0.4 \mathrm{~mm}$, usually spaced widely, curved downwardly or occasionally almost straight, with small spines; apophyses four, spines more prominent and numerous than on arms, apophyses almost straight, mostly broken at their ends even in better preserved specimens, apophyses length up to $0.35 \mathrm{~mm}$ (Figure 1E-L). Ventral ossicles similar to dorsal in shape, but smaller and slender; arms curved, up to $0.35 \mathrm{~mm}$, apophyses four, up to $0.2 \mathrm{~mm}$, spiny (Figure 1M,N). Calcareous ring pieces with 9 pairs of arms, which can be subdivided. Polian vesicle single.

Genetic data. No genetic data is available for this species.

Etymology. The name minuta indicates the relatively small size of this species.

Distribution. Aleutian and Izu-Bonine trenches, at 6850-7315 m; one record in the northwest Pacific abyssal plain at $5850 \mathrm{~m}$. Type locality in the Aleutian Trench, off Atka Island.

Remarks. Specimens collected at Vityaz stations 3491, 6015, 6085, 6144, 6145, 7404 and 7407 were identified as Peniagone gracilis (Ludwig) by Gebruk [22] as well as the North Atlantic specimens from St. 390-3 of RV Akademik Mstislav Keldysh. Re-examination of the syntypes of Scotoanassa gracilis Ludwig NMNH 18178 and 18179 revealed remarkable differences in ossicle morphology: (i) ossicles in the syntypes were smaller than in P. minuta, their arms rarely exceeded $0.2 \mathrm{~mm}$ in length; (ii) apophyses were usually longer than arms. Unfortunately, both syntypes were in poor condition lacking details of external morphology. According to Ludwig [35], the syntypes were up to $68 \mathrm{~mm}$ long suggesting that $P$. gracilis exceeds $P$. minuta in body length.

Gebruk [22] assigned P. japonica Ohshima to $P$. gracilis based on details of external and ossicle morphology in the original description [7]. Peniagone japonica is known from three stations off Japan at 1142-1680 m and is characterized by body length $55 \mathrm{~mm}$, eight pairs of tube feet, dorsal deposits with bent arms $0.12-0.2 \mathrm{~mm}$ long and four apophyses $0.7-0.12 \mathrm{~mm}$ long, and ventral ossicles of similar shape to those on dorsum, with arms $0.09-0.14 \mathrm{~mm}$ and apophyses $0.02-0.05 \mathrm{~mm}$ long. Although the shape of ossicles is similar in P. minuta and $P$. japonica, ossicles in P. japonica are remarkably smaller and this distinguishes this species from P. minuta.

Peniagone minuta is characterized by the relatively small size, oval shape and a small number of tube feet, the features clearly distinguishing it from most of other species of the genus. Such a body shape and a small tube feet number are known in preferentially swimming species such as P. diaphana (Théel) and P. leander Pawson et Foel.

\subsection{Peniagone mus Djakonov, 1952}

Figure 2J-M, Figure 3A,B and Figure 4.

Peniagone mus Djakonov, 1949: 68 [nomen nudum] [36].

Peniagone mus Djakonov, 1952: 122-124, Figures 7-10 [10].

Peniagone incerta (Théel)—Gebruk, 1990 (in Russian): 108-109 [partim.], Figure 42 (8-11) [22].

Peniagone aff. incerta-Mironov et al. 2019: 11-12 [4].

Type material. Two syntypes ZIN 12313-1, RV Severnyj Polyus, St. A, 25.07.1946, Sigsbee Trawl, $52.75^{\circ} \mathrm{N}, 161.68^{\circ} \mathrm{E}, 4100-4200 \mathrm{~m}$, http:/ / zin.ru/collections/Holothuroidea/ specimen.html?Catalog_UID=1344281483486918 (accessed on 12.10.2021). 
Material examined. (In addition to material listed in Mironov et al. 2019 [4]). Syntype slide preparation of ventral ossicles; RV Vityaz, St. 956, 29.09.1951, Sigsbee Trawl, $55^{\circ} 11^{\prime} \mathrm{N}, 163^{\circ} 26^{\prime} \mathrm{E}, 4810-4990 \mathrm{~m}, 50$ specimens (IORAS ECH01101 and ECH01109); St. 116, 28.08.1954, Sigsbee Trawl, 51 ${ }^{\circ} 53.1^{\prime} \mathrm{N}, 161^{\circ} 49.6^{\prime} \mathrm{E}, 5803-5853 \mathrm{~m}$, IORAS ECH01949, 1 specimen; St. 3214, 24.10.1954, Sigsbee Trawl, $38^{\circ} 10.9^{\prime} \mathrm{N}, 143^{\circ} 56.2^{\prime} \mathrm{E}, 6156-6207 \mathrm{~m}$, IORAS ECH02008, 6 specimens; St. 4120, 05.11.1958, Sigsbee Trawl, 53 $37^{\prime} \mathrm{N}, 159^{\circ} 40^{\prime} \mathrm{E}$, 6328-6296 m, IORAS ECH01287, 1 specimen; St. 5609, 23.07.1966, Sigsbee Trawl, 46 $06^{\prime}$ N, $153^{\circ} 18^{\prime}$ E, 6090-6235 m, IORAS ECH01243, 11 specimens; St. 5633, 06.09.1966, Galathea Trawl, 44 ${ }^{\circ}{ }^{\prime} \mathrm{N}, 149^{\circ} 34^{\prime} \mathrm{E}, 6156-6117 \mathrm{~m}, \sim 300$ specimens (IORAS ECH01227, ECH01230, ECH01248 and ECH01374[in formalin]); RV Akademik M.A. Lavrentiev, cruise 71 (SokhoBio), St. 10-07, 29.07 2015, Epibenthic sledge, $46^{\circ} 06.0^{\prime}-46^{\circ} 05.8^{\prime} \mathrm{N}, 152^{\circ} 14.4^{\prime}-152^{\circ} 14.6^{\prime} \mathrm{E}$, 4769-4798 m, 13 specimens; RV Sonne, cruise 223 (KuramBio), St. 03-10, 05.08.2012, Agassiz Trawl, $47^{\circ} 14.27^{\prime}-47^{\circ} 14.94^{\prime} \mathrm{N}, 154^{\circ} 42.17^{\prime}-154^{\circ} 43.18^{\prime} \mathrm{E}, 4977-4986 \mathrm{~m}, 16$ specimens (ID KB301,

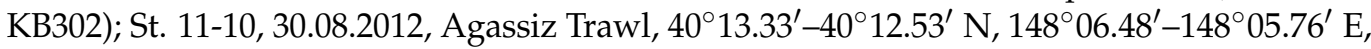
5348-5347 m, 1 specimen (ID KB1416); RV Sonne, cruise 250 (KuramBio II), St. 18, 22.08.2016, Agassiz Trawl, $45^{\circ} 50.861^{\prime}-45^{\circ} 51.954^{\prime} \mathrm{N}, 153^{\circ} 49.568^{\prime}-153^{\circ} 51.259^{\prime} \mathrm{E}, 8200-8185 \mathrm{~m}, 3$ specimens (ID KB2_428); St. 31, 28.08.2016, Agassiz Trawl, 4556.688' $45^{\circ} 56.544^{\prime}$ N, $152^{\circ} 52.785^{\prime}-152^{\circ} 54.667^{\prime} \mathrm{E}, 6184.5-6220.6 \mathrm{~m}$, IORAS ECH02146- ECH02148, ECH01808, ECH01812, ECH01813, 11 specimens; St. 86, 15.09.2016, Agassiz Trawl, 45¹.202' N, $151^{\circ} 6.008^{\prime} \mathrm{E}, 5572-5530 \mathrm{~m}, 6$ specimens.

Diagnosis. Body elongated, approximately three times as long as wide. Colour in alcohol grey. Tube feet up to 10 pairs, present in the anterior $1 / 3$ to 1 / 4 of the body, anteriormost five pairs free, others forming posterior lobe. Velum broad and short, formed by two pairs of papillae. Dorsal ossicles with strongly bent arms $0.1-0.3 \mathrm{~mm}$ long; apophyses two, rarely 1,3 or $4,0.09-0.2 \mathrm{~mm}$ long; apophyses and central stem thicker than arms. Ventral ossicles with arms $0.07-0.12 \mathrm{~mm}$ in length.

Material description. Body length up to $75 \mathrm{~mm}$ (Figure 3A,B and Figure 4A,B). Ten tentacles. Anus dorsal. Skin rough owing to the dense layer of ossicles. Velum varying in size, depending on contraction at preservation; velum did not cover the anterior end of the body and tentacles in most preserved specimens, suggesting its relatively small size in live specimens. Free tips of papillae short in preserved state, $<5 \mathrm{~mm}$ long, lost in most of the specimens. Dorsal ossicles (Figure 2J-L and Figure $4 \mathrm{C}-\mathrm{H}$ ) with strongly bent arms, sometimes almost vertical, 0.08-0.25 mm long, rarely exceed $0.3 \mathrm{~mm}$; apophyses usually two, rarely 3 or 4 and occasionally 1 apophysis can be found, apophyses almost vertical, 0.09-0.2 mm long in most ossicles. Apophyses usually slightly shorter than arms, although ossicles with much shorter apophyses also found (Figure 2L). Arms and apophyses spinous, on apophyses spines more conspicuous. In bigger ossicles apophyses usually long and straight located close to each other. Ventrally flatten Peniagone-type ossicles, with arms $0.07-0.12 \mathrm{~mm}$ in length, spines conspicuous; short spinous apophysis on each arm (Figures $2 \mathrm{M}$ and $4 \mathrm{I}-\mathrm{K}$ ). Calcareous ring pieces with 9-10 pairs of arms, which can be subdivided. Polian vesicle single.

Genetic data. See Table S1.

Distribution. Common in the Kuril-Kamchatka Trench area at abyssal and hadal depths, and also found in the Japan and Aleutian trenches (Figure 11). Depth range 4200-8200 m.

Remarks. Original description is based on three damaged specimens with upper layer of dorsal skin lacking, of which only two specimens are remain preserved. Djakonov [36] at first mentioned this species without describing any taxonomic characters significant at the species level. In the later description [10], details of external morphology and ventral ossicles were given. The dorsal ossicles illustrated in the original description on the Figure 10 apparently occur in the deeper skin layer and cannot be used for species identification. Our examined specimens were assigned to $P$. mus based on unique features of ventral ossicles illustrated by Djakonov [10]. 
Peniagone mus differs from other species of the genus by the type of dorsal ossicles with two apophyses clearly thicker than arms. Peniagone mus resembles P. incerta (Théel) in having five pairs of larger free tube feet, two of them located in the anterior body half and dorsal ossicles with nearly vertical apophyses straight and closely placed, usually two, rarely three or four. The re-examination of the syntype of Elpidia incerta Théel NHM 83.6.18.7 revealed remarkable variation in the morphology of dorsal ossicles in this species. Despite an obvious similarity in shape, ossicles of the syntype appeared significantly slender and smaller than in P. mus: arms and apophyses did not exceed 0.2 and $0.17 \mathrm{~mm}$ respectively, with most arms $0.1 \mathrm{~mm}$ in length.

Specimens from the northwest Pacific identified by Gebruk [22] as P. incerta were re-examined and found to belong to $P$. mus (except for the specimens from stations 2144 and 2208, apparently lost).

\subsection{Peniagone cf. purpurea (Théel, 1882)}

Figure 5A,B,F-M.

Peniagone purpurea (Théel)—Gebruk, 1990 (in Russian): 111-113 (partim.), Figures 3-8 [22].

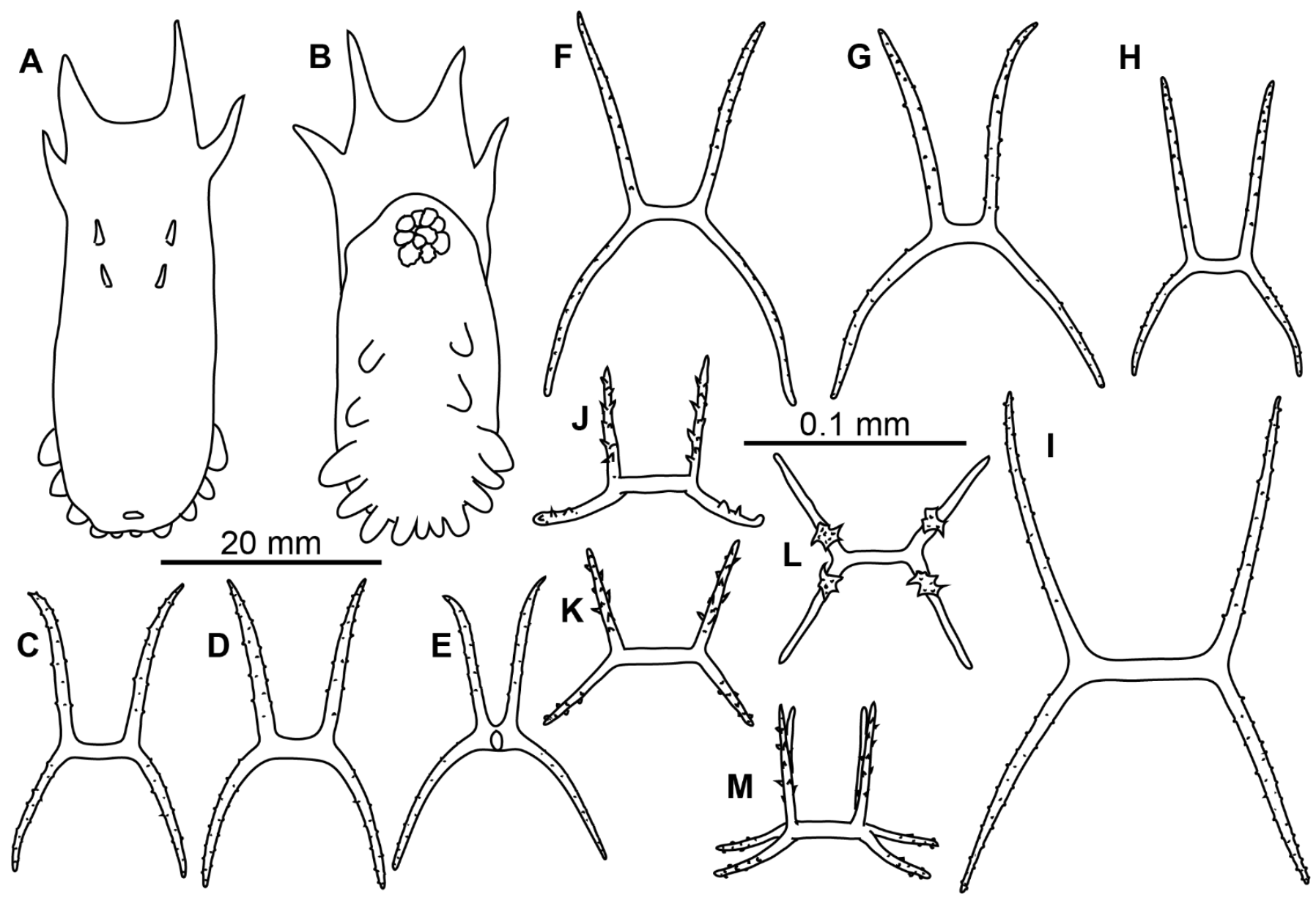

Figure 5. Peniagone cf. purpurea, RV Sonne, St. 01-13: (A,B) dorsal and ventral view, (F-I) dorsal ossicles, (J-M) ventral ossicles. (C-E), syntype of Elpidia purpurea NHM 83.6.18.4, dorsal ossicles. (C-M) scale $0.1 \mathrm{~mm}$; pair of arms and apophyses omitted on $(\mathbf{C}-\mathbf{J})$. 


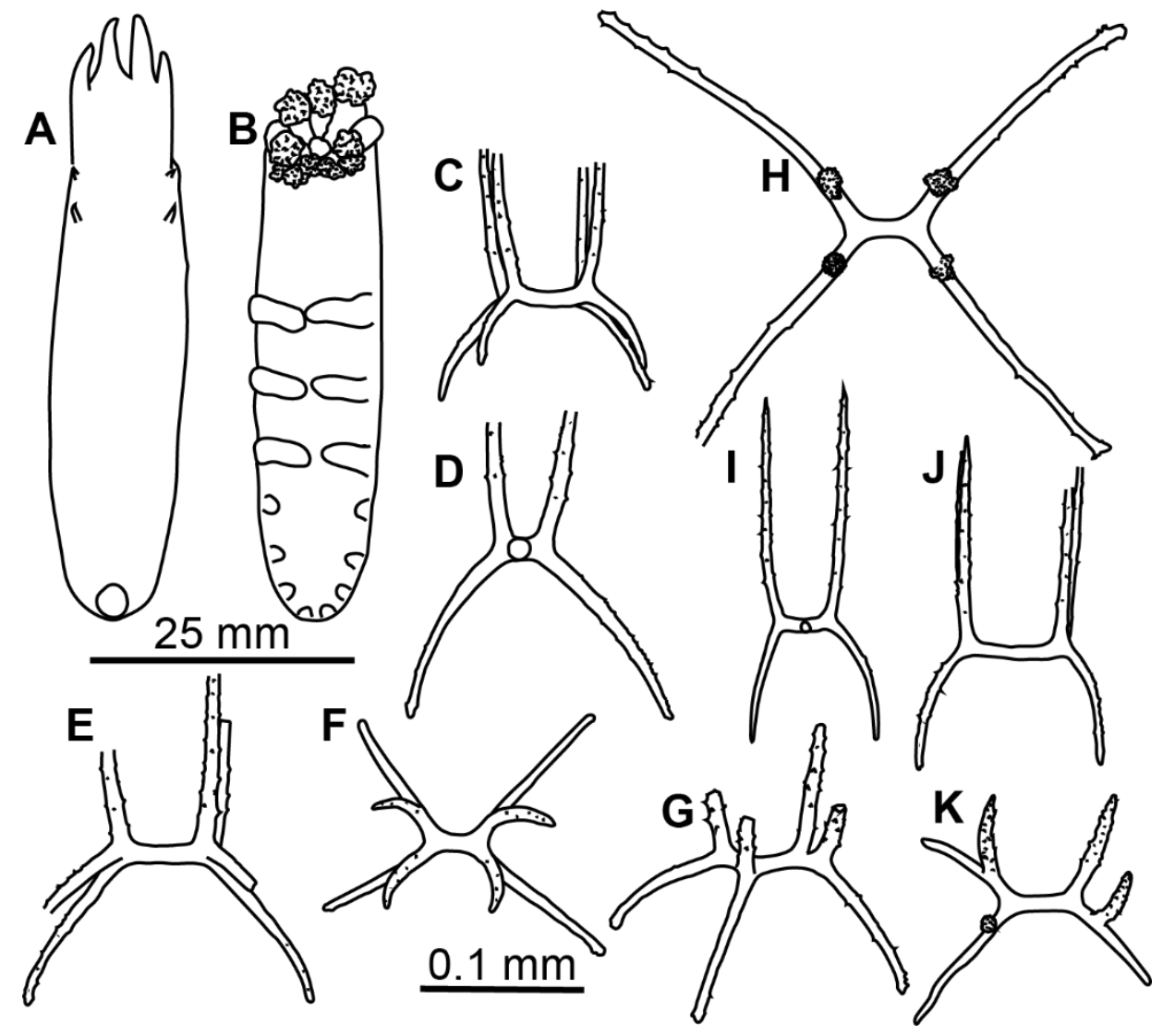

Figure 6. Peniagone saveljevae sp. nov., paratype: (A,B) dorsal and ventral view; (C-G), dorsal ossicles; (I-K) ventral ossicles.

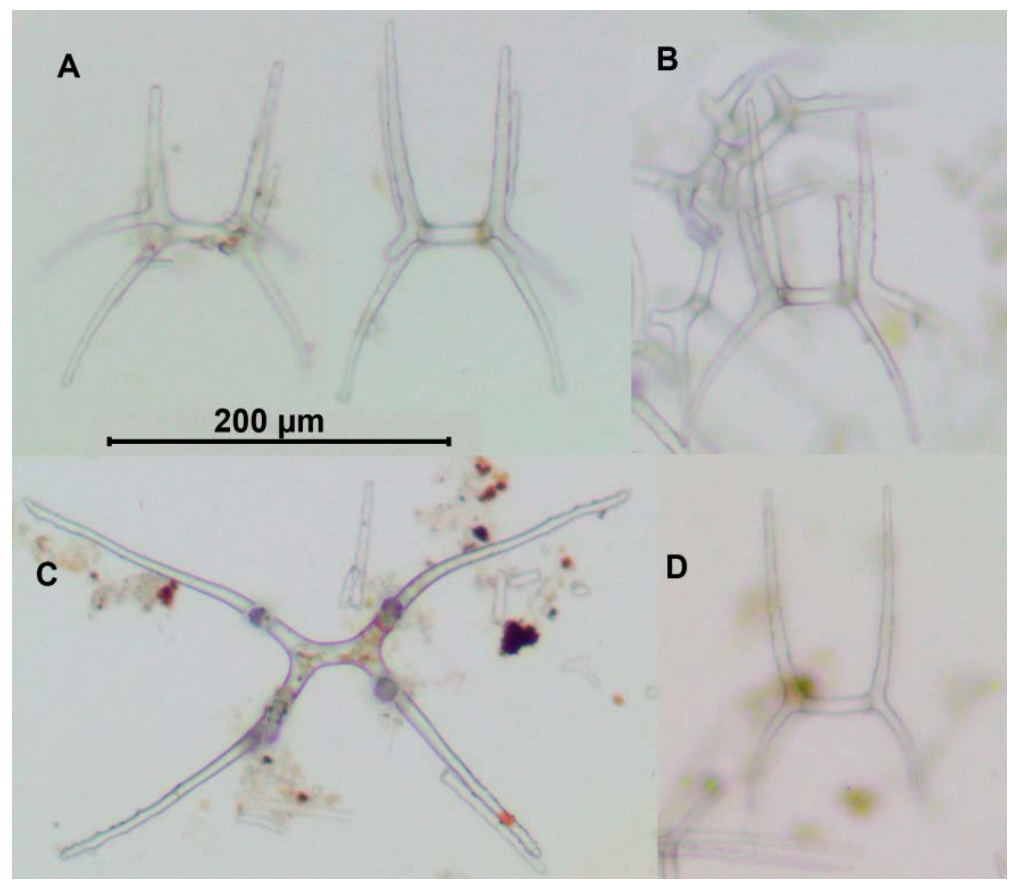

Figure 7. Peniagone saveljevae sp. nov., paratype: (A,B) dorsal ossicles; (C,D) ventral ossicles. 

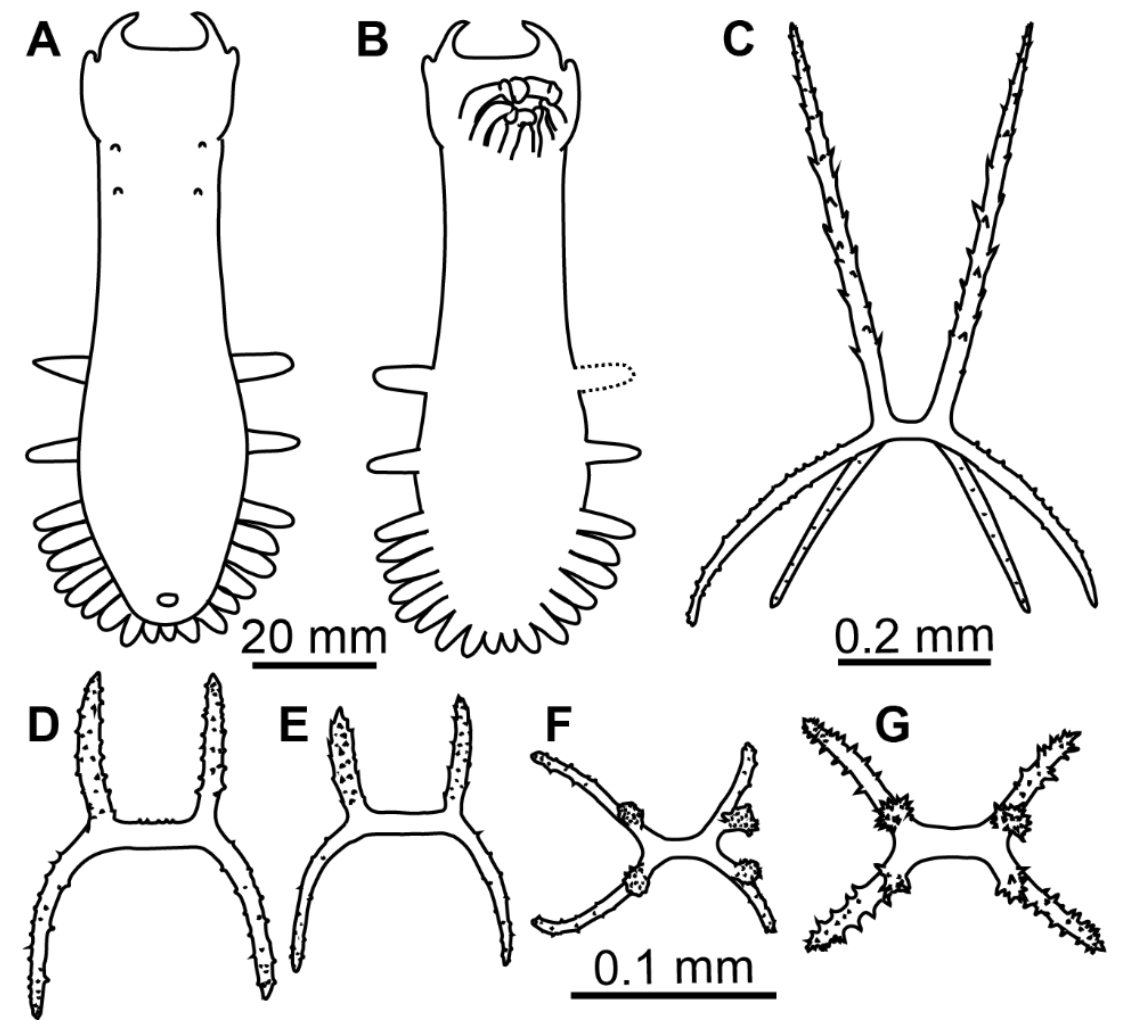

Figure 8. Peniagone vitrea (A-C) and Peniagone sp. "miniatura" (D-G). (A-C), RV Vityaz, St. 5603. (A,B) dorsal and ventral view; (C) dorsal ossicle, scale $0.2 \mathrm{~mm}$. (D-G) RV Sonne, St. 6-9, dorsal (D-F) and ventral (G) ossicles, scale $0.1 \mathrm{~mm}$.

Material examined. RV Vityaz, St. 5620, 15.08.1966, $44^{\circ} 48^{\prime} \mathrm{N}, 156^{\circ} 33^{\prime} \mathrm{E}, 5045-5005 \mathrm{~m}$, IORAS ECH02013, 4 specimens; RV Sonne, cruise 223 (KuramBio), St. 01-12, 30.07.2012, $43^{\circ} 58.19^{\prime}-43^{\circ} 57.81^{\prime} \mathrm{N}, 157^{\circ} 19.11^{\prime}-157^{\circ} 21.58^{\prime}$ E, 5422-5379 m, IORAS ECH01811, 1 spec-

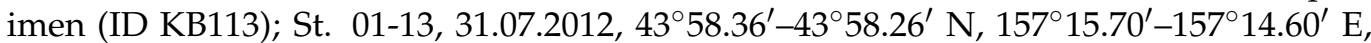
5427-5425 m, IORAS ECH01810, 2 specimens (ID KB83, KB96); St. 06-09, 14.08.2012, $42^{\circ} 29.25^{\prime}-42^{\circ} 28.32^{\prime} \mathrm{N}, 154^{\circ} 00.05^{\prime}-153^{\circ} 59.73^{\prime} \mathrm{E}, 5293-5307 \mathrm{~m}$, 1 specimen (ID KB2080).

Additional material. Syntypes of Elpidia purpurea Théel, NHM 83.6.18.4 and NHM 83.6.18.5 (slide preparation of dorsal ossicles).

Material description. Specimens $16-40 \mathrm{~mm}$ in length, condition from poor to moderated. Body close to oval, flattened (Figure 5A,B). Ten big tentacles. Colour in alcohol from brownish to dark or black violet. Tube feet 7-9 pairs, missing in the anterior third of the body; first 2-3 pairs free, other tube feet forming posterior lobe. Velum large, long and wide, may exceed in length $\frac{1}{2}$ of the body length; free ends of velum papillae long. Two pairs of small papillae on dorsum behind velum. Dorsal ossicles (Figure 5F-I) with central stem of varying proportions-from $1 / 3$ of arm length to the same length with arms or even slightly longer; arms straight or slightly curved, arm length $0.05-0.12 \mathrm{~mm}$, usually up to $0.1 \mathrm{~mm}$. Apophyses four, longer than arms, but not exceeding $0.1 \mathrm{~mm}$ in length, apophyses slightly curved outwardly (Figure 5F,G), straight (Figure $5 \mathrm{H}$ ) or inwardly curved (Figure 5I). Ventral ossicles (Figure 5J-M) with arms curved outwards (Figure 5J,L) or straight (Figure $5 \mathrm{~K}$ ), arm length about $0.05 \mathrm{~mm}$; apophyses four, longer than arms, about $0.07 \mathrm{~mm}$ in length. Arms and apophyses spinous both in dorsal and ventral ossicles. Calcareous ring pieces with 7 pairs of arms, which can be subdivided. Some of the arms are multiply branched at their ends. Polian vesicle single.

Genetic data. See Table S1.

Distribution. Five records in the Kuril-Kamchatka Trench area and on abyssal plain east of the trench. Depth 5005-5427 m. 
Remarks. By external morphology, examined specimens corresponded well to the original description of Peniagone purpurea in colour, shape of the body, velum morphology, tube feet and dorsal papillae number and arrangement. Re-examination of the syntypes of Elpidia purpurea NHM 83.6.18.4 and NHM 83.6.18.5 revealed some differences between them and our specimens in the dorsal ossicle morphology. In the syntypes, apophyses were curved outwardly in most of dorsal ossicles (Figure 5C-E), whereas in the northwest Pacific specimens they were either straight or curved inward. Additionally, ossicles of the syntypes were smaller: arms up to $0.08 \mathrm{~mm}$ and apophyses up to $0.07 \mathrm{~mm}$. However, ossicle size and shape of apophyses in the northwest Pacific specimens varied between the stations. Specimens from St. 5620 had the biggest ossicles with arms up to $0.12 \mathrm{~mm}$ and apophyses up to $0.1 \mathrm{~mm}$. The apophyses in most ossicles were placed more widely and slightly curved inwardly, although few ossicles with apophyses curved outwardly were also present. In the northwest Pacific specimens from other stations the arm length of ossicles was $<0.1 \mathrm{~mm}$ long and apophyses were straight or outwardly curved. The variation in dorsal ossicles of P. purpurea requires further studies, therefore at present we identify our specimens as Peniagone cf. purpurea.

\subsection{Peniagone saveljevae Kremenetskaia et Gebruk sp. nov.}

Figure 3C,D, Figures 6 and 7.

Holotype. Specimen $60 \mathrm{~mm}, \mathrm{RV}$ Akademik M.A. Lavrentiev, cruise 71 (SokhoBio), St. 01-11, 11.07.2015, Agassiz Trawl, 46 $09.047^{\prime}-46^{\circ} 08.738^{\prime} \mathrm{N}, 146^{\circ} 00.789^{\prime}-145^{\circ} 59.512^{\prime} \mathrm{E}$, 3305-3304 m. The specimen will be deposited at MIMB, currently stored at IORAS, Cat. Nr ECH02165.

Paratypes. 3 specimens $45-50 \mathrm{~mm}$ in length, collected at the same station as the holotype. Paratypes will be deposited at SGN, currently stored at IORAS, Cat. Nr ECH02164 and ECH02151.

Diagnosis. Body elongated, approximately 3-4 times as long as wide. Color in alcohol grey. Tube feet up to $\sim 8$ pairs, missing in the anterior $1 / 3$ of the body. Velum broad and short, formed by two pairs of papillae. Two pairs of small papillae behind velum. Dorsal ossicles with curved arms up to $0.15 \mathrm{~mm}$ long; apophyses four, up to $0.12 \mathrm{~mm}$ long; apophyses slightly thicker than arms. Ventral ossicles with curved arms $0.07-0.1 \mathrm{~mm}$ in length and four apophyses longer than arms, up to $0.14 \mathrm{~mm}$, or with more horizontal arms up to $0.2 \mathrm{~mm}$.

Material description. Body strongly elongated (Figure 3C,D and Figure 6A,B). Skin rather thick, almost non-transparent in preserved state. Ambulacral appendages and tentacles are mostly lost, few tube feet are preserved in the paratype, IORAS ECH02151. In the latter only 7 pairs of tube feet are present, however some small posteriormost tube feet might have been lost. Arms and apophyses of dorsal ossicles spinous; spines on apophyses more numerous (Figure 6C-G and Figure 7A,B). Apophyses in dorsal ossicles of the same length with arms or slightly shorter (in ossicles with widely spaced arms); arms usually $\sim 0.1 \mathrm{~mm}$ long. Apophyses always four, slightly curved inward. Ventral ossicles (Figure 6I-K and Figure 7C,D) usually of the same shape as dorsal but slenderer and smaller in size, with arms usually $<0.1 \mathrm{~mm}$ long and apophyses slightly longer or equal in length with arms. Occasionally present flatten Peniagone-type ossicles, with four short apophyses or sometime with no apophyses. Polian vesicle single.

Genetic data. See Table S1.

Etymology. The species is named in honor of Tatyana Sergeyevna Saveljeva (1902-1982), a Soviet zoologist and expert on Holothuroidea.

Distribution. The species is known only from the type locality in the southern part of the Sea of Okhotsk.

Remarks. Peniagone saveljevae resembles $P$. dubia and P. mus in external morphology within the group of the northwest Pacific species, however it differs by the absence of tube feet in the anteriormost third or fourth of the body and small velum. The tube feet in the anterior half of the body is a common feature in Peniagone occurring in Peniagone islandica 
Deichmann, P. azorica von Marenzeller, P. willemoesi (Théel), P. herouardi Gebruk, P. vedeli Hansen and other species. This type of morphology suggests more epibenthic lifestyle. Peniagone saveljevae also differs by the dorsal ossicles with four apophyses and curved arms up to $0.15 \mathrm{~mm}$ long.

\subsection{Peniagone vitrea Théel, 1882}

Figure 8A-C.

Peniagone vitrea Théel, 1882: 50-52, Plates VII(7-9), XXXIV(17-18), XLIV(10) [5]; Hansen, 1975: 148-150, Figure 70 [synonymy] [24]; Gebruk, 1990 (in Russian): 93-94, Figure 34(4-9) [synonymy] [22]; O’Loughlin, 1998: 504 [37].

Peniagone vitrea var. setosa Ludwig, 1893: 109; 1894: 105-108 [38].

Peniagone setosa Ludwig-Clark, 1920: 136 [39].

Material examined. RV Vityaz, St. 5603, 15.07.1966, Sigsbee Trawl, $46^{\circ} 22^{\prime} \mathrm{N}, 153^{\circ} 3^{\prime} \mathrm{E}$, 3175-3250 m, IORAS ECH01201, 3 specimens; St. 5635, 08.09.1966, Galathea Trawl, $44^{\circ} 24^{\prime} \mathrm{N}$, $149^{\circ} 10^{\prime}$ E, 3900-4135 m, IORAS ECH00236, 14 specimens and fragments.

Genetic data. No genetic data is available for examined specimens.

Distribution. Type locality is off southern Chile at the depth $2652 \mathrm{~m}$ (1450 fathoms), Challenger, St. 302. Other confirmed records are in the Eastern and Central Pacific, off Australia, and Antarctic (Figures 11 and 12). The new records are from the northwest Pacific, Kuril-Kamchatka Trench area. Depth range 1360-4507 m. There are also about 30 records published in GBIF.org [40] from the Eastern Pacific, off Australia and New Zealand identified by P.M. O'Loughlin, N. Davey and D. Pawson.

Remarks. Peniagone vitrea currently has two junior synonyms: $P$. vitrea var. setosa Ludwig and P. setosa Ludwig. Hansen [24] has re-examined the type series of P. vitrea and found pronounced variation in ossicle size among the types of the synonymized species and the specimens from the Central and East Pacific reported by Clark [39] and from Galathea St. 716. The biggest ossicles were in the Galathea specimen with the arms reaching $0.7 \mathrm{~mm}$ in length whereas in the type specimens the arms were $0.3-0.5 \mathrm{~mm}$ long. In our specimens from the northwest Pacific the arms in the dorsal ossicles (Figure 8C) attained $0.4 \mathrm{~mm}$, with 2-4 apophyses, rather straight, longer than arms and spinous. External morphology of these specimens (Figure 8A,B) corresponded well to that in the original description of the species. The body was strongly elongated, velum lobe broad and short, tube feet bordering from posterior half to one third of the body and forming broad posterior lobe.

\subsection{Peniagone sp. "miniatura"}

Figure 8D-G.

Material examined. RV Sonne, cruise 223 (KuramBio), St. 6-9, 14.08.2012, Agassiz Trawl, $42^{\circ} 29.25^{\prime}-42^{\circ} 28.32^{\prime} \mathrm{N}, 154^{\circ} 00.05^{\prime}-153^{\circ} 59.73^{\prime} \mathrm{E}, 5293-5307 \mathrm{~m}$, IORAS ECH01809, 1 specimen.

Material description. Body $65 \mathrm{~mm}$ long, elongated, approximately three times as long as wide. Color in alcohol greyish. Dorsal velum long, may exceed in length 1/3 that of the body; papillae free at most of their length. Tube feet $\sim 11$ pairs, present in anterior $1 / 3$ of the body; six pairs free, posterior five pairs closely placed; tube feet mostly lost, their arrangement can be determined based on ampullae position. Dorsal ossicles (Figure 8D-F) rare, with arms almost straight or slightly curved, arm length $0.09-0.11 \mathrm{~mm}$. Apophyses four (rarely three), shorter than arms, 0.05-0.06 $\mathrm{mm}$ in length. Arms and apophyses bare small spines. Central stem slightly shorter than apophyses or of similar length. Ventral ossicles (Figure 8G) with straight arms $0.06-0.08 \mathrm{~mm}$ in length, arms slightly curved horizontally and/or vertically to varying degree; apophyses short, $<\frac{1}{2}$ of the arm length. Arms and apophyses spinous.

Genetic data. See Table S1. Genetic data on both COI and 16 S shows very small difference between Peniagone sp. "miniatura" and P. mus, up to $2.5 \%$. It can be suggested that the observed morphological and genetic differences are related to an ongoing speciation process. 
Remarks. This possibly new species has distinctive features of the ossicles, but in external morphology it is very similar to P. mus. Dorsal ossicles in Peniagone sp. "miniatura" are much smaller, mostly with four apophyses which do not form a dense layer in the skin.

\section{Phylogeny}

Peniagone was recovered monophyletic in both COI and 16S analyses as well as in concatenated dataset analysis with PP $=1.0$ (Figure S1). COI tree (Figure 9) included six previously described species (P. cf. purpurea, $P$. diaphana, P. coccinea, $P$. vignoni, $P$. incerta and $P$. islandica) that were either recovered monophyletic $(\mathrm{PP}=1.00)$ or were represented by a single specimen. Peniagone cf. purpurea was one of the most basal species with COI pdistance to other Peniagone species varying from 18.2 to $24.5 \%$. Peniagone mus was sister with Peniagone sp. "miniatura" with PP $=0.99$. The COI p-distance between these clades was $2.5 \%$, whereas it varied from 5 to $26 \%$ between other species clades. The clade of P. mus did not form sister relationships with the morphologically similar Antarctic species $P$. incerta to which the specimens of $P$. mus were previously assigned.

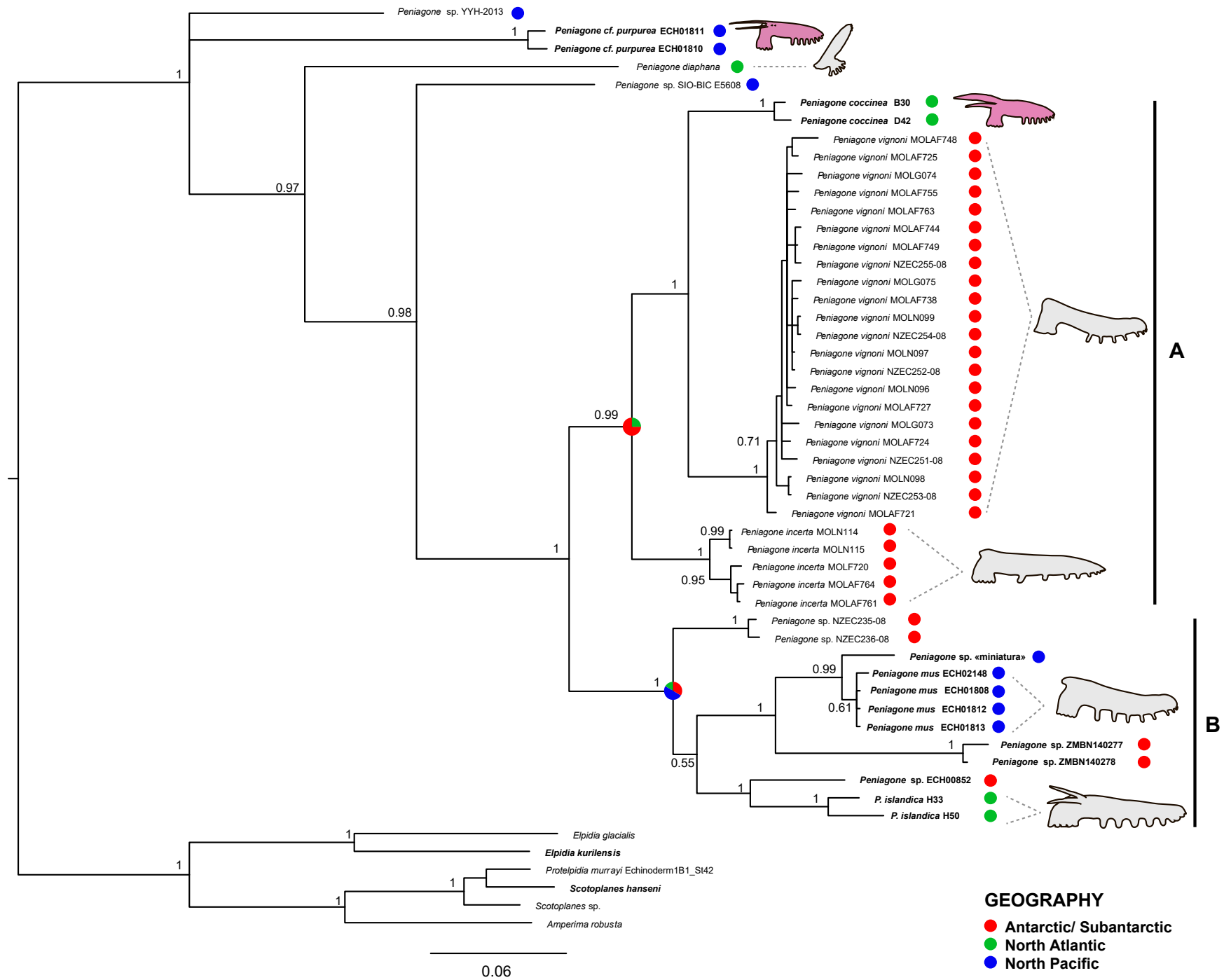

Figure 9. Bayesian phylogenetic tree inferred from mtDNA COI sequences. Sequences obtained in this study are in bold. Node numbers are posterior probabilities. NZEC2XX-08 correspond to BOLD process ID numbers. Holothurian pictograms are colored according to the color of preserved specimens.

$16 \mathrm{~S}$ tree (Figure S1) included six previously described species (P. cf. purpurea, P. leander, $P$ diaphana, $P$. azorica and $P$. islandica) however was generally much less resolved. Further- 
more, P. azorica and P. islandica were not recovered as monophyletic species. Similarly to the COI tree, a clade composed of $P$. mus and P. sp. "miniatura" was recovered with PP $=0.94$. 16S p-distances showed $0.7 \%$ difference between $P$. mus and Peniagone sp. "miniatura", whereas it varied from $0.4 \%$ to $12.8 \%$ between the other species. Peniagone saveljevae was only present as a single specimen in $16 \mathrm{~S}$ tree showing no close relationships to any of the other species in the analysis.

Analysis of the concatenated COI and $16 S$ matrix included nine previously described species although as in $16 \mathrm{~S}$ tree $P$. islandica and P. azorica did not form monophyletic clades. Nevertheless, the topology of the recovered tree was generally similar to the one from the COI analysis with slightly lower support in most of the nodes. Similar to the COI tree, P. cf. purpurea, P. diaphana and two unidentified Peniagone species (Peniagone sp. YYH-2013 and Peniagone sp. SIO-BIC E5608) appeared in the basal part of the tree and the rest of the species were split into two large sister clades A and B (PP = 0.89) (Figure 10). Additionally, $P$. leander lacking COI sequence data was recovered as sister to $P$. diaphana $(\mathrm{PP}=0.93)$ similar to the $16 \mathrm{~S}$ tree (Figure 10).

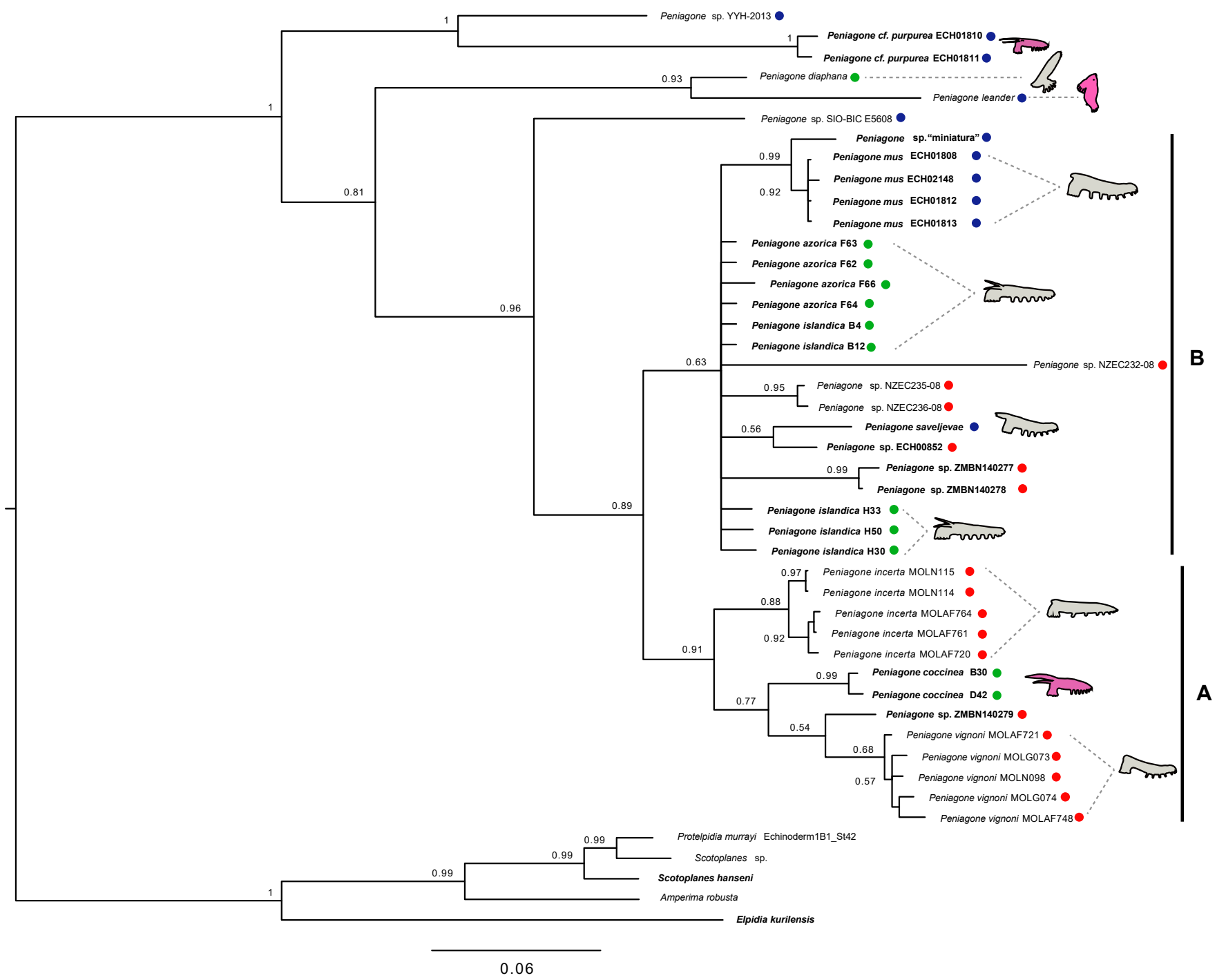

Figure 10. Bayesian phylogenetic tree inferred from concatenated mtDNA COI and 16S RNA sequences. Sequences obtained in this study are in bold. Node numbers are posterior probabilities. NZEC2XX-08 correspond to BOLD process ID numbers. Holothurian pictograms are colored according to the color of preserved specimens. Colored circles correspond to geographical locations as on Figure 9. 
In all three trees, the basal-most species were reported from the North Pacific ( $P$. cf. purpurea, Peniagone spp., P. leander) and the North Atlantic (P. diaphana), while the terminal clades (A and B) also included all the Antarctic species. The North Pacific species included in the present study (P. cf. purpurea, P. mus and P. saveljevae) did not show close relationship to each other appearing in the different larger clades on the phylogenetic trees. Occasionally swimming forms [3] were mostly found within the terminal clades A and B (Figures 9 and 10) although morphology of Peniagone sp. YYH-2013 and Peniagone sp. SIO-BIC E5608 specimens was not reported in the open sources and thus was not scored in the present study. Notably, two species with large velum and bright coloration, $P$. cf. purpurea and P. coccinea did not form sister relationships on the obtained phylogenetic trees (Figures 9 and 10).

\section{Discussion}

According to previously published records and our results, the northwest Pacific fauna of the genus Peniagone includes at least seven species: P. dubia, P. japonica, P. mus, P. minuta, P. cf. purpurea, P. saveljevae and P. vitrea. The northwest Pacific Peniagone sp. "miniatura" can also represent a separate species or a case of ongoing speciation within P. mus. Although genetically it is very close to $P$. mus, the differences in the ossicle morphology between the two potential species are remarkable. A similar case was described by Elgetany et al. [41] as a grey zone of speciation in the two polychaete species, Diopatra aciculata Knox et Cameron and D. neapolitana Delle Chiaje. Although some statistical differences were found in several morphological characters, these species displayed low genetic distances: up to $<0.0359$ for COI data and $<0.00028$ for $16 \mathrm{~S}$.

All the examined species are not known outside the northwest Pacific except for P. vitrea (Figures 11 and 12). The latter is the example of a widespread species occurring widely in the Pacific with one record in the Pacific sector of the Antarctic. Morphological differences suggest separation of the northwest Pacific Peniagone cf. purpurea from Peniagone purpurea described from the southern Indian Ocean. Some genetic evidence also point on that $P$. purpurea might represent a species complex. Six sequences of P. purpurea obtained from the Antarctic specimens are deposited in the BOLD database [42]. According to the scheme of abyssal biogeography of Vinogradova [43], these specimens were collected from one biogeographic subregion including the type locality of $P$. purpurea. Although these sequences are stored privately and are not currently available for phylogenetic analysis, they do not cluster under the same Barcode Index Number (BIN) with the northwest Pacific P. cf. purpurea from the present study (BOLD: AEI4563) indirectly suggesting they might not be conspecific. Furthermore, the nearest neighbor BIN (BOLD: ABA3279) comprising these Antarctic specimens shows $7.53 \%$ p-distance in COI with the northwest Pacific bin which corresponds to the level of genetic distances between other Peniagone species.

Most northwest Pacific species are distributed in a relatively narrow depth range (Figure 11) although this can be partly explained by the low number of specimens collected from the deep sea. The shallowest species is P. dubia inhabiting the lower bathyal ( 2500-3000 m). Peniagone saveljevae occurs in the upper abyssal $(\sim 3300 \mathrm{~m})$ in the Sea of Okhotsk. Peniagone vitrea in the northwest Pacific is known from the upper to mid-abyssal $(\sim 3200-4100 \mathrm{~m})$ although it occurs in a slightly wider range in other areas $(\sim 1300-4500 \mathrm{~m})$. Peniagone cf. purpurea is the lower abyssal species ( $\sim 5300 \mathrm{~m})$. Peniagone $m u s$ and P. minuta are the only two species occurring in the hadal in trenches. Peniagone minuta was repeatedly found in the Aleutian and Izu-Bonine trenches as well as on the abyssal plain. Peniagone mus is the deepest and the most eurybathic species (4200-8200 m) among the northwest Pacific Peniagone. It is mainly known from the Kuril-Kamchatka Trench and adjacent abyssal areas, with single records in the Aleutian and Japan trenches. 


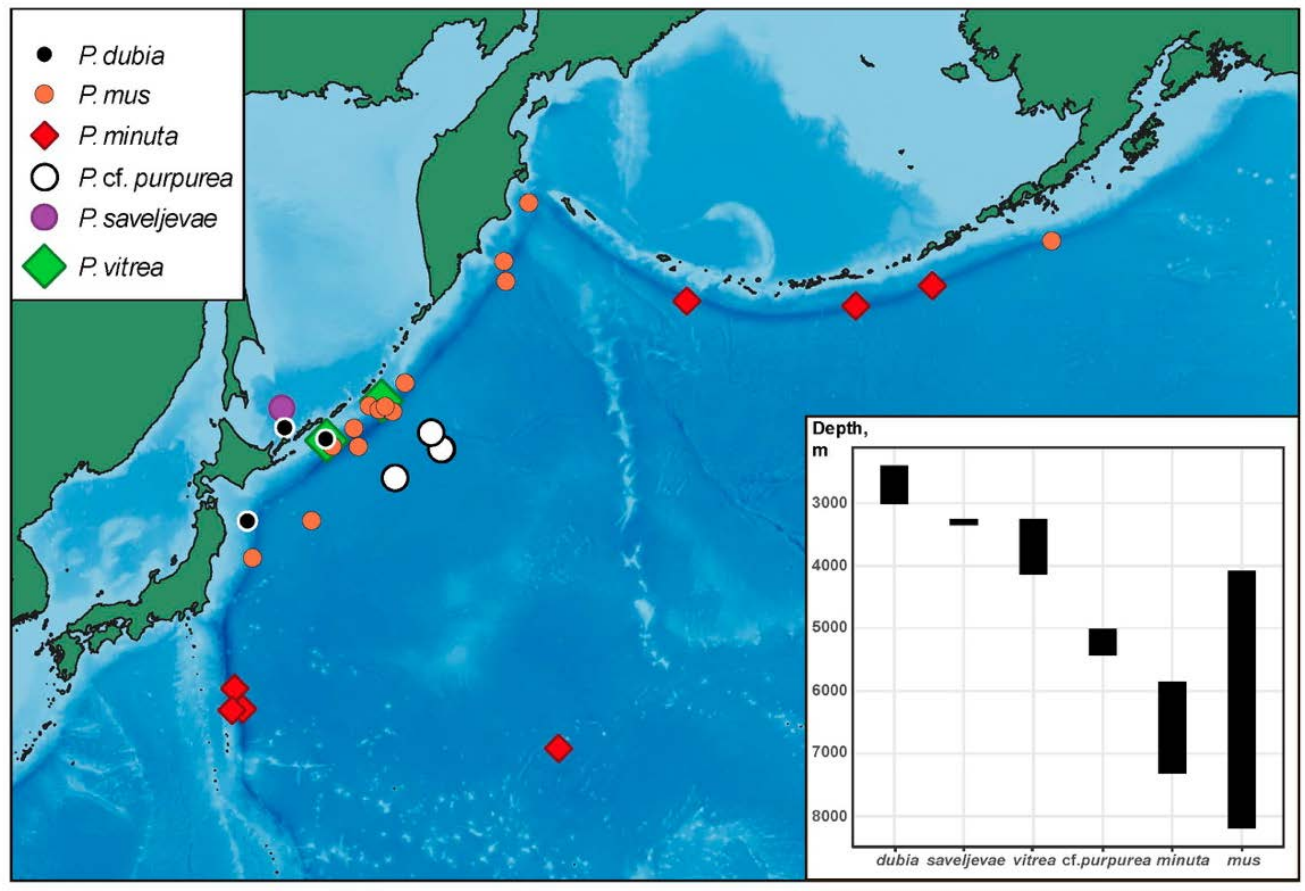

Figure 11. Geographic distribution and bathymetric range of the examined species in the northwest Pacific.

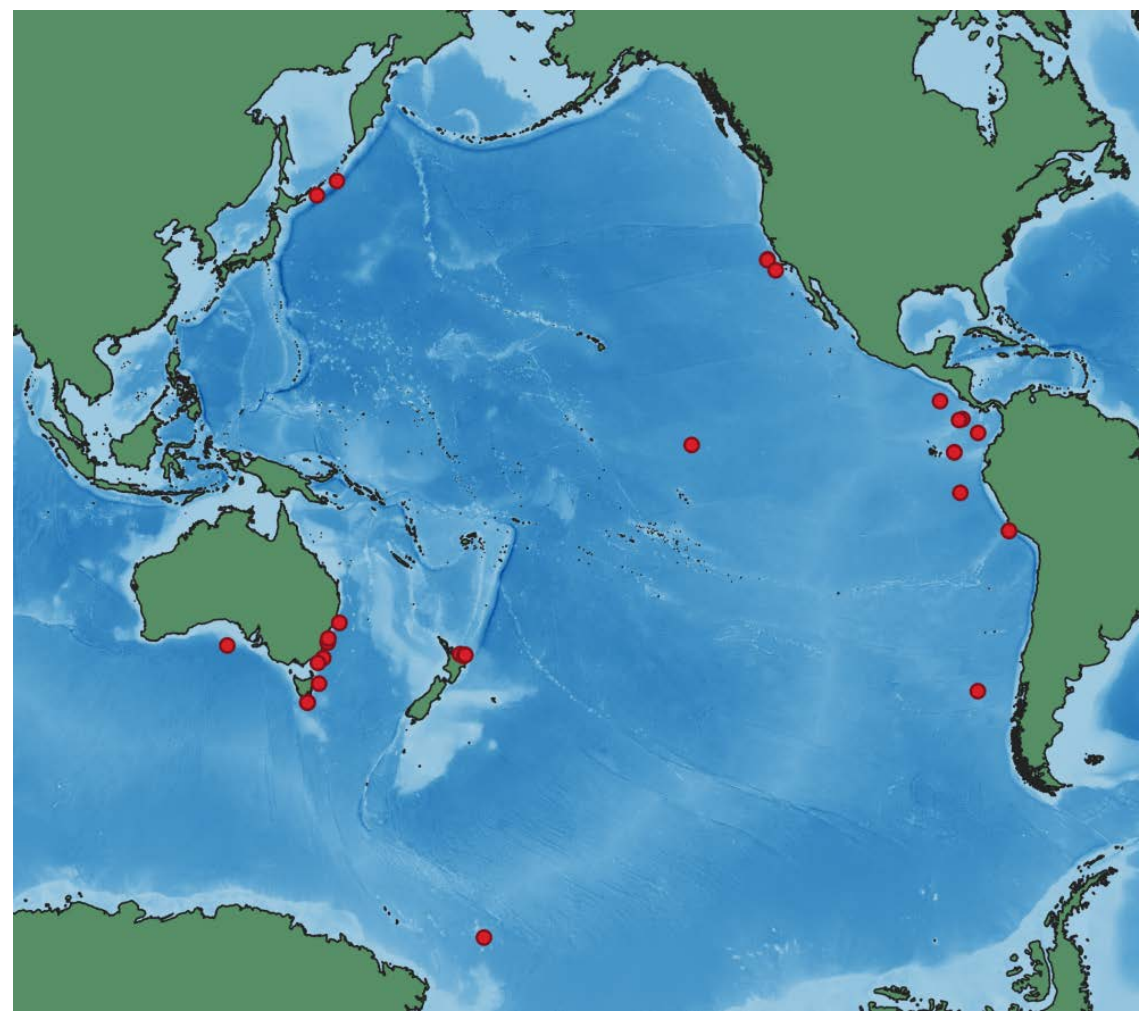

Figure 12. Global distribution of Peniagone vitrea.

Surprisingly, Peniagone is absent in the relatively well studied Bering Sea. It can be explained by possible interspecies interactions. Rybakova et al. [44] showed the abyssal community in the Bering Sea being dominated by another elpidiid species, Kolga kamchatica Rogacheva. The latter may occupy the same trophic niche as Peniagone replacing Peniagone species in the Bering Sea. 
No clear geographic affinity was revealed for the main clades within Peniagone according to molecular data (Figures 9 and 10). The northwest Pacific species appeared not closely related. Following more resolved COI tree (Figure 9), P. mus is the closest to the Antarctic species Peniagone sp. ZMBN140277 and ZMBN140278 whereas west Pacific P. cf. purpurea and Peniagone sp. YYH-2013 [unpublished], and east Pacific Peniagone sp. SIO-BIC E5608 [45] are placed distantly from all other species. The same pattern was revealed for the Atlantic species, P. diaphana from northeast Atlantic [45], and P. coccinea and P. islandica from the northern Mid-Atlantic Ridge. The Atlantic P. azorica and P. islandica are closely related species, which are almost indistinguishable by external morphological features, but differ in dorsal ossicle morphology [3]. Analysis of their 16S, 18S, 28S rRNA and histone $\mathrm{H} 3$ sequences, showed clear separation of these species only in H3 data which may indicate ongoing speciation (CA, unpublished data). The Antarctic species, several of which were unidentified, were located only in terminal clades and absent in the basal part of the tree (Figures 9 and 10). However, our data represent only a fraction of Peniagone diversity and obtaining genetic data for other species worldwide may change the picture.

Rogacheva et al. [3] described several adaptive forms within the genus Peniagone with different swimming abilities. Occasionally swimming forms possess more tube feet bordering most of the body and small velum and tentacles which apparently facilitate "walking" mode of life. In more active swimmers the number of tube feet is reduced and velum is either large as in P. coccinea, or reduced as in P. diaphana, P. leander and P. minuta.

Forms that are proposed to be occasionally swimming, such as $P$. islandica, $P$. mus, P. incerta and others, are present in terminal clades A and B (Figures 9 and 10). However, they can potentially be also found among more basal taxa depending on the external morphology (yet unknown) in Peniagone sp. SIO-BIC E5608 and Peniagone sp. YYH-2013. More advanced swimmers bearing large velum and lacking tube feet in the anterior body half such as $P$. diaphana and $P$. cf. purpurea occur in two separate clades suggesting their independent evolution. The species with almost completely reduced tube feet and very modified body shape presumably with predominantly pelagic life style, $P$. diaphana and $P$. leander, are closely related following our molecular data. Nevertheless, since the external morphology is not well described for some species in our analysis, and many species of the genus lack genetic data, the analysis of evolution of characters adaptive to swimming based on the obtained phylogenetic tree appears preliminary.

Supplementary Materials: The following are available online at https:/ / www.mdpi.com/article/10 $.3390 /$ d13110541/s1, Table S1: Specimen list with GenBank Accession numbers and data on their sampling, storage and sequences. Table S2: List of sequences obtained from GenBank and BOLD. Figure S1. Bayesian phylogenetic tree inferred from mtDNA $16 \mathrm{~S}$ rDNA sequences. Sequences obtained in this study are in bold. Node numbers are posterior probabilities.

Author Contributions: Conceptualization, A.K. and A.G.; morphology, A.K. and A.G.; molecular lab work, A.K., C.H.S.A. and N.B.; phylogenetic analysis, A.K. and N.B.; writing, A.K., A.G. and N.B.; illustrations, A.K. All authors have read and agreed to the published version of the manuscript.

Funding: The research was funded by the MINISTRY OF SCIENCE AND HIGHER EDUCATION, RUSSIAN FEDERATION, grant number 13.1902.21.0012, contract number 075-15-2020-796.

Institutional Review Board Statement: Not applicable.

Data Availability Statement: Sequences obtained in this study are uploaded to GenBank and BOLD (Table S1). Specimen records are published on GBIF [23].

Acknowledgments: We thank Angelika Brandt, Marina Malyutina, Kirill Minin, captains and crew of all three German-Russian cruises as well as benthic invertebrate teams involved in collecting and preservation of samples. We would like to thank Anne Helene Solberg Tandberg for collecting Antarctic holothurians during the R/V Kronprins Haakon Expedition to Kong Håkon VII Hav 2019, and Imants Priede and scientific and technical team of the ECOMAR project for collecting samples in the North Atlantic. We are very grateful to Louise Lindblom for her great help and assistance in the DNA lab (University of Bergen), Jon Kongsrud and Katrine Kongshavn for providing specimens for genetic 
analysis. Examination of the Antarctic collections and molecular works at the University of Bergen was supported via the Cooperation Programme between Norway and Russia "Multidisciplinary EDUcation and reSearch in mArine biology in Norway and Russia" (MEDUSA), the Norwegian Agency for International Cooperation and Quality Enhancement in Higher Education. We also thank Andrew Cabrinovic and David and Doris Pawson for their help during the stay at NHM and NMNH.

Conflicts of Interest: The authors declare no conflict of interest.

\section{References}

1. WoRMS. Peniagone Théel. 1882. Available online: http:/ / www.marinespecies.org/aphia.php?p=taxdetails\&id=123515 (accessed on 28 April 2021).

2. Gebruk, A.V.; Smirnov, A.V.; Rogacheva, A.V. Holothuroidea. In Deep-Sea Fauna of European Seas: An Annotated Species Check-List of Benthic Invertebrates Living Deeper than $2000 \mathrm{~m}$ in the Seas Bordering Europe; Gebruk, A.V., Thiel, H., Thurston, M.H., Eds. Invert. Zool. 2014, 11, 156-180. [CrossRef]

3. Rogacheva, A.; Gebruk, A.; Alt, C.H.S. Holothuroidea of the Charlie-Gibbs Fracture Zone area, northern Mid-Atlantic Ridge. Mar Biol. Res. 2013, 9, 587-623. [CrossRef]

4. Mironov, A.N.; Dilman, A.B.; Gebruk, A.V.; Kremenetskaia, A.V.; Minin, K.V.; Smirnov, I.S. Echinoderms of the Kuril-Kamchatka Trench. Prog. Oceanogr. 2019, 179, 102217. [CrossRef]

5. Théel, H. Report on Holothurioidea. Part I. Rep. Sci. Results Voyag. H.M.S. Challenger. Zool. 1882, 4, 1-176.

6. Mitsukuri, K. Studies on Actinopodous Holothurioidea. J. Coll. Sci. Tokyo Imp. Univ. 1912, 29, 1-284.

7. Ohshima, H. Report on the Holothurians Collected by the United States Fisheries Steamer Albatross in the Northwestern Pacific during the Summer of 1906. Proc. US Natl. Mus. 1915, 48, 213-291. [CrossRef]

8. Saveljeva, T. On the holothurian fauna of the Japan and Okhotsk Seas. Issled. Daln. Morej SSSR 1933, 19, 37-58.

9. Saveljeva, T.S. On the holothurian fauna of the USSR Far Eastern Seas. Issled. Daln. Morej SSSR 1941, 1, 73-103.

10. Djakonov, A.M. Echinoderms from abyssal depths in the waters around Kamtchatka. Issled. Daln. Morej SSSR $1952,3,116-130$.

11. Djakonov, A.M.; Baranova, Z.I.; Saveljeva, T.S. Notes on the Holothuroidea of the southern Sakhalin and South Kurile Islands area. Issled. Daln. Morej SSSR 1958, 5, 358-380.

12. Baranova, Z.I. Echinoderms of the Bering Sea. Issled. Daln. Morej SSSR 1957, 4, 149-266.

13. Belyaev, G.M. Ultra-abyssal holothurians of the genus Myriotrochus (Order Apoda, Fam. Myriotrochidae). Tr. Instituta Okeanol. 1970, 86, 458-486.

14. Belyaev, G.M.; Mironov, A.N. The holothurians of the family Myriotrochidae (Apoda): Composition, Distribution and Origin. Tr Instituta Okeanol. 1982, 117, 81-120.

15. Belyaev, G.M. Deep-sea holothurians of the genus Elpidia. Tr. Instituta Okeanol. AN SSSR 1971, 92, $326-367$.

16. Rogacheva, A. Taxonomy and distribution of the genus Kolga (Elpidiidae: Holothuroidea: Echinodermata). J. Mar. Biol. Assoc. UK 2012, 92, 1183-1193. [CrossRef]

17. Gebruk, A.V.; Kremenetskaia, A.; Rouse, G.W. A group of species "Psychropotes longicauda" (Psychropotidae, Elasipodida, Holothuroidea) from the Kuril-Kamchatka Trench area North-West Pacific. Prog. Oceanogr. 2020, 180, 102222. [CrossRef]

18. Brandt, A.; Malyutina, M.V. The German-Russian deep-sea expedition KuramBio (Kurile Kamchatka Biodiversity Studies) on board of the RV Sonne in 2012 following the footsteps of the legendary expeditions with RV Vityaz. Deep Sea Res. Part II Top. Stud. Oceanogr. 2015, 111, 1-9. [CrossRef]

19. Malyutina, M.V.; Chernyshev, A.V.; Brandt, A. Introduction to the SokhoBio (Sea of Okhotsk Biodiversity Studies) expedition 2015. Deep Res. Part II Top. Stud. Oceanogr. 2018, 154, 1-9. [CrossRef]

20. Brandt, A.; Brix, S.; Riehl, T.; Malyutina, M. Biodiversity and biogeography of the abyssal and hadal Kuril-Kamchatka Trench and adjacent NW Pacific deep-sea regions. Prog. Oceanogr. 2020, 181, 102232. [CrossRef]

21. Mironov, A.N.; Minin, K.V.; Kremenetskaia, A.V. Two new genera of the family Myriotrochidae (Echinodermata, Holothuroidea). Prog. Oceanogr. 2019, 178, 102195. [CrossRef]

22. Gebruk, A.V. Deep-Sea Holothurians of the Elpidiidae Family; Nauka: Moskva, Russia, 1990.

23. Kremenetskaia, A.; Gebruk, A. Holothurians of the Genus Peniagone (Elasipodida: Elpidiidae) from the Northwest Pacific Ocean. Shirshov Institute of Oceanology, Russian Academy of Sciences. Occurrence Dataset. 2021. Available online: https: / / doi.org/10.15468/s2vncb (accessed on 7 July 2021). [CrossRef]

24. Hansen, B. Systematics and biology of the deep-sea holothurians. Galathea Rep. 1975, 13, 1-262.

25. Arndt, A.; Marquez, C.; Lambert, P.; Smith, M.J. Molecular phylogeny of eastern Pacific sea cucumbers (Echinodermata: Holothuroidea) based on mitochondrial DNA sequence. Mol. Phylogenet. Evol. 1996, 6, 425-437. [CrossRef] [PubMed]

26. Folmer, O.; Black, M.; Hoeh, W.; Lutz, R.; Vrijenhoek, R. DNA Primers for amplification of mitochondrial cytochrome C oxidase subunit I from diverse metazoan invertebrates. Mol. Mar. Biol. Biotechnol. 1994, 3, 294-299.

27. Hoareau, T.B.; Boissin, E. Design of phylum-specific hybrid primers for DNA barcoding: Addressing the need for efficient COI amplification in the Echinodermata. Mol. Ecol. Resour. 2010, 10, 960-967. [CrossRef]

28. Layton, K.K.S.; Corstorphine, E.A.; Hebert, P.D.N. Exploring Canadian Echinoderm diversity through DNA barcodes. PLoS ONE 2016, 11, e0166118. [CrossRef] 
29. Palumbi, S.R. The Simple Fool's Guide to PCR; Department of Zoology and Kewalo Marine Laboratory, University of Hawaii: Honolulu, HI, USA, 1991.

30. Priede, I.G.; Bergstad, O.A.; Miller, P.I.; Vecchione, M.; Gebruk, A.; Falkenhaug, T.; Billett, D.S.M.; Craig, J.; Dale, A.C.; Shields, M.A.; et al. Does Presence of a Mid-Ocean Ridge Enhance Biomass and Biodiversity? PLoS ONE 2013, 8, e61550. [CrossRef] [PubMed]

31. Kumar, S.; Stecher, G.; Tamura, K. MEGA7: Molecular Evolutionary Genetics Analysis Version 7.0 for Bigger Datasets. Mol. Biol. Evol. 2016, 33, 1870-1874. [CrossRef]

32. Lanfear, R.; Frandsen, P.B.; Wright, A.M.; Senfeld, T.; Calcott, B. PartitionFinder 2: New methods for selecting partitioned models of evolution for molecular and morphological phylogenetic analyses. Mol. Biol. Evol. 2017, 34, 772-773. [CrossRef] [PubMed]

33. Ronquist, F.; Teslenko, M.; van der Mark, P.; Ayres, D.L.; Darling, A.; Höhna, S.; Larget, B.; Liu, L.; Suchard, M.A.; Huelsenbeck, J.P. MrBayes 3.2: Efficient Bayesian phylogenetic inference and model choice across a large model space. Syst. Biol. 2012, 61, 539-542. [CrossRef] [PubMed]

34. Mironov, A.N.; Minin, K.V.; Dilman, A.B.; Smirnov, I.S. Deep-Sea echinoderms of the Sea of Okhotsk. Deep. Res. Part II Top. Stud. Oceanogr. 2018, 154, 342-357. [CrossRef]

35. Ludwig, H. The Holothurioidea. In Reports on an exploration off the west coasts of Mexico, Central and South America, and off the Galapagos Islands, in charge of Alexander Agassiz, by the U.S. Fish Commission Steamer Albatross, during 1891. Mem. Mus. Compar. Zool. Harvard Coll. 1894, 17, 1-183.

36. Djakonov, A.M. Key to the Echinoderms of the Far Eastern Seas. Izv. Tikhookeanskogo N. I. Instituta Rybn. Khozyaistva i Okeanogr. 1949, 30, 1-130.

37. O'Loughlin, P.M. Elasipod holothurians from the continental slope of Australia. In Echinoderms: San Fancisco, Proceedings of the Ninth International Echinoderm Conference San Francisco, CA, USA, 5-9 August 1996; Mooi, R., Telford, M., Eds.; Balkema: Rotterdam, The Netherlands, 1998; pp. 499-504.

38. Ludwig, H. Vorläufiger Bericht über die erbeuteten Holothurien. In: Reports on the Dredging Operations off the West Coast of Central America to the Galapagos, etc., by the U. S. Fish Commission Steamer Albatross. IV. Bull. Compar. Zool. Harvard Coll. 1893, 24, 105-114.

39. Clark, H.L. Holothurioidea. In Reports Sci. Results Exped. Trop. Pacific, V. 22; Reports Sci. Results Exped. to East. Trop. Pacific, v. 33. Mem. Museum Comp. Zool. Harvard Coll. 1920, 39, 115-154.

40. GBIF.org. GBIF Occurrence Download. Available online: https://doi.org/10.15468/dl.2dnzrk (accessed on 15 April 2021). [CrossRef]

41. Elgetany, A.H.; van Rensburg, H.; Hektoen, M.; Matthee, C.; Budaeva, N.; Simon, C.A.; Struck, T.H. Species delineation in the speciation grey zone-The case of Diopatra (Annelida, Onuphidae). Zool. Scr. 2020, 49, 516-534. [CrossRef]

42. Ratnasingham, S.; Hebert, P.D.N. BOLD: The Barcode of Life Data System: Barcoding. Mol. Ecol. Notes 2007, 7, 355-364. [CrossRef] [PubMed]

43. Vinogradova, N.G. Zoogeography of the Abyssal and Hadal Zones. Adv. Mar. Biol. 1997, 32, 325-387.

44. Rybakova, E.; Galkin, S.; Gebruk, A.; Sanamyan, N.; Martynov, A. Vertical distribution of megafauna on the Bering Sea slope based on ROV Survey. PeerJ 2020, 2020, e8628. [CrossRef] [PubMed]

45. Miller, A.K.; Kerr, A.M.; Paulay, G.; Reich, M.; Wilson, N.G.; Carvajal, J.I.; Rouse, G.W. Molecular Phylogeny of Extant Holothuroidea (Echinodermata). Mol. Phylogenet. Evol. 2017, 111, 110-131. [CrossRef] 